\title{
The nZEB concept and its requirements for residential buildings renovation in Southern Europe: The case of multi-family buildings from 1961 to 1980 in Portugal and Spain
}

\author{
Marta Monzón-Chavarrías ${ }^{\mathrm{a}}$, Belinda López-Mesa ${ }^{\mathrm{a}, *}$, Jaime Resende ${ }^{\mathrm{b}}$, Helena Corvacho ${ }^{\mathrm{b}}$

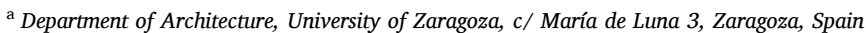 \\ ${ }^{\mathrm{b}}$ CONSTRUCT (LFC), Faculty of Engineering (FEUP), University of Porto, Rua Dr. Roberto Frias, s/n, 4200-465, Porto, Portugal
}

\section{A R T I C L E I N F O}

\section{Keywords:}

Nearly zero energy buildings (nZEB)

Building renovation

Multi-family housing

Residential building stock

Southern Europe

\begin{abstract}
A B S T R A C T
Southern Europe has an old housing stock and has the challenge, as the rest of European Union Member States, to transform it into a decarbonized one, by means of transforming the existing buildings into Nearly Zero Energy Buildings (nZEB). Member States have a large margin of discretion when defining the requirements for nZEB.

In this paper, the nZEB requirements for the renovation of residential buildings in Portugal and Spain are studied in detail (unlike the usual more general comparative studies) for a specific building typology with poor energy performance. This is done by checking whether an existing residential building, renovated with different combinations of improvements of the envelope and active systems in two comparable cities in each of these two countries, fulfills the requirements or not, and by comparing the results of $\mathrm{CO}_{2}$ emissions reductions. One of the improvements of the envelope considered are those necessary to fulfill the compulsory major renovation requirements in both countries to check how much we are already approaching to the decarbonization of the residential sector.

The results show that nZEB standards applied to the renovation of typical multi-family buildings of 1961-1980 in both countries will significantly contribute to the descarbonization of the building stock for this type of building typology, with reductions of $80-96 \%$ of $\mathrm{CO}_{2}$ emissions for Portugal and 71-94\% for Spain, if they are applied. However, some aspects of the regulations could possibly be improved such as more restrictive requirements for the current regulations for major renovations in Portugal or the way energy from renewable sources is ensured in Spain, among others.
\end{abstract}

\section{Introduction}

Given that almost $50 \%$ of the European Union's (EU) final energy consumption is used for heating and cooling, out of which $80 \%$ is used in buildings [1], the European Parliament has promoted different directives for energy efficiency in the buildings sector. The Energy Performance of Buildings Directive (EPBD) 2010/31/EU [2] establishes as a requirement that all new buildings must be nearly Zero Energy Buildings (nZEB) [3] from the end of 2020. This was already a requirement for all new public buildings from the end of 2018 on. A nZEB is a building that has a very high-energy performance, in which the nearly zero or very low amount of energy required should be covered to a very significant extent by energy from renewable sources, including that produced on-site or nearby. Additionally, according to this directive, Member States (MS) had to take the necessary measures to ensure that when buildings undergo major renovation, the energy performance of the building or the renovated part thereof was upgraded in order to meet minimum energy performance requirements. The renovation of the building stock is of great importance to achieve the European objectives due to the long lifespans in the buildings sector [4,5]. Besides energy savings, retrofitting of buildings can improve thermal comfort and indoor air quality [4], and can have a positive impact in terms of people's health and in terms of economic savings to the country's healthcare system [5].

The Energy Performance of Buildings Directive (EPBD) was recently amended by Directive 2018/844 of the European Parliament and of the

\footnotetext{
* Corresponding author.

E-mail addresses: monzonch@unizar.es (M. Monzón-Chavarrías), belinda@unizar.es (B. López-Mesa), jaimeresende@hotmail.com (J. Resende), corvacho@fe.up. pt (H. Corvacho).
} 
Council in order to accelerate buildings deep renovation in the EU, among other things [1,6]. According to it, MS should create a clear path towards achieving a low and zero-emission building stock in the Union by 2050 , underpinned by national roadmaps with milestones and domestic progress indicators, and by public and private financing and investment [1].

In a mid-term scenario, energy demand for air conditioning will increase rapidly in the 21 st century, and the demand for heating increases too, but at a much slower rate [7]. Buildings should be adapted to the climate change, and for this reason, energy retrofitting of the existing buildings stock should become the main priority for the future [8]. However, in general, the European nZEB guidelines are more concerned with cold climate conditions. Bioclimatic strategies should be re-evaluated to integrate, in the design of new nZEBs and renovations towards nZEB, guidelines for both heating and cooling seasons [9]. In Southern Europe this is still more important. To avoid the overheating of the building during summer the amount of solar radiation transmitted through the transparent building surfaces must be controlled [10].

The EPBD leaves to MS a large margin of discretion when designing their building codes and implementing technical requirements regarding renovations, building certificates and building systems so that they can make them fit the national climate conditions and building stocks [11]. Thermal characteristics of building envelope are some of the main regulatory instruments, because it is easy to change their values and they are directly related to the building energy demand [12]. According to the literature, nZEB in Southern European countries lack climate adapted metrics and concepts, and this is relevant because Southern Europe's buildings stock represent more than 33\% of the European total residential building stock [13].

Some authors study the environmental benefits of energy retrofitting towards nZEB using different solutions. For example, Fotopoulou et al. [14] study the energy saving potential of transforming a residential building into a nZEB in three countries, Italy, Greece and Latvia, through façade and volumetric additions, as reference solutions towards energy renovation. Escandon et al. [15] study energy savings using a retrofitting strategy designed for Dutch housing stock adapted to a Mediterranean climate and its technical implications. These studies are of great interest to explore the possibilities of different technical solutions but do not make a thorough analysis of the nZEB requirements because the focus is not on the regulation, but on the technical solutions.

Some studies aim at optimizing the renovation design process. For example, Ituriaga et al. [16] describe a method to achieve the optimal renovation design that limits the annual cost and energy demand. This method is applied to a multi-family existing building located in Bilbao (Spain). Guardigli et al. [17] propose a decision support system for the assessment of different renovation strategies through the estimation of their economic sustainability in relation to the achievement of energy efficiency, adopting Italian laws and regulations. These studies provide interesting methodologies for the implementation of nZEB standards in the renovation of buildings, but do not carry out a critical analysis of existing regulations.

Other authors, do explore the concept of nZEB by analyzing the regulation. They normally make a comparative study of the requirements for new nZEBs and renovations towards nZEB in different countries. For example, Attia et al. [13] study the nZEB regulation situation in Southern Europe, for Cyprus, France, Greece, Italy, Portugal, Romania and Spain. The authors identify that most of the Southern European countries are poorly prepared for nZEB implementation and especially for the challenge of transforming existing buildings into nZEBs. D'Agostino and Mazzarella include in their study up to 31 countries [3]. Since these studies cover both, new buildings and renovations, for a high number of countries, they draw general conclusions about the regulations, and not specific ones such as those regarding the methodology for calculation. Additionally, even if these general studies are of great interest, the regulations have significantly evolved since they were published and therefore their conclusions are partially outdated.

López-Mesa et al. found that social residential buildings erected between 1945 and 1969 with higher internal thermal mass can meet the nZEB renovation requirements more easily than those with lower thermal mass [18]. Therefore, when studying the nZEB regulation in detail, it is important to do it typology by typology. This implies not only distinguishing between new buildings and renovations, but also between the different uses of buildings, the building typologies (e.g. multi-family, single-family buildings, etc.), and the constructive typology normally linked to the year of construction [19].

Since the concept of nZEB is still being revised in the different European countries, and its application to renovations is quite a recent challenge, the study of the regulations at a higher detail level for the case of renovations is an important input for policy makers and science. In this paper, the main novelties are that: i) we study in detail the most recent regulations for renovation towards nZEB; ii) we do the analysis in detail for a specific typology for two countries with comparable climates. The novelties are therefore methodological, since the approach is more specific, and provide not only general results but also specific for the typology of study.

The majority of buildings in Portugal (77\%) and Spain (66\%), are residential $[20,21]$. In these countries, most of the buildings were built before 1980, 53.5\% in Portugal and 56.3\% in Spain, i.e. before the first energy saving regulations for buildings were approved [22,23]. Therefore, these buildings do not have any thermal insulation. The decades 1961-1980 are typically considered as a period with buildings with a poor energy performance in these two countries. For example, Gangolells et al. [24] studied $20 \%$ of energy certificates issued in Spain up to 2016 , and found that the vast majority $(94.3 \%)$ of the residential buildings or building units erected before 1980 were rated E, F or G for the indicator of $\mathrm{CO}_{2}$ emissions. López-González et al. [25] studied the energy performance certificates in a region of Spain (la Rioja) showing that $94.32 \%$ of buildings erected between 1961 and 1980 were rated E, F or $\mathrm{G}$ for the indicator of nonrenewable energy consumption and $90.91 \%$ of them obtained $\mathrm{E}, \mathrm{F}$ or $\mathrm{G}$ for the indicator of $\mathrm{CO}_{2}$ emissions. Las-Heras-Casas [26] studied the energy performance certificates in a region of Spain (Aragón), and found that the buildings erected between 1961 and 1980 have a $33.19 \%$ higher primary energy consumption and a $44.47 \%$ higher $\mathrm{CO}_{2}$ emissions than those built after 2007. Sousa et al. [27] studied the constructive solutions and energy performance of Portuguese buildings, and argue that buildings erected during the 60 's, 70 's and 80's are the ones with highest energy saving potential. Magalhães and Leal [28] studied the energy performance certificates of residential buildings in Portugal, and found that buildings erected before 1980 have higher levels of nominal heating energy needs. We have selected the multi-family residential buildings of the period 1961-1980 as our typology of study.

The main objective of this paper is to compare in detail the energy requirements for the envelope when transforming existing residential buildings into nZEBs in two countries, Portugal and Spain, and to compare their resulting $\mathrm{CO}_{2}$ emissions when applied to typical multifamily residential buildings of the period 1961-1980, with the aim to underline advantages and disadvantages of the present regulations in each of the countries for this building typology in order to derive future recommendations.

\section{Material and methods}

The research work is addressed by means of a case study. For the sake of comparability, the same building in terms of geometry is used as a case study in both countries. Since the goal is not to present an optimization of the envelope energy performance, but to compare the actions necessary to meet the requirements of each country, the calculations are done with the tools provided by each country.

The methodology is composed of the following steps: 
- Study the nZEBs regulation in the case of Portugal and identify the specific requirements for nZEB renovation, which are the same as for new buildings and not mandatory. In the case of Spain, there are specific requirements for nZEB renovation which are not mandatory.

- Identify comparable case studies. This step implies:

a) The identification of cities with similar climate and geographical characteristics in both countries. Two pairs of cities fulfilling this condition were identified.

b) The identification of a typical residential building in both countries which must be refurbished in the coming years. This typical building is selected as a case study for simulation in the two pairs of Southern European cities.

- Establish different scenarios that consider different levels of the envelope thermal improvement and different cooling, heating and domestic hot water (DHW) solutions.

- Study the compliance with the national nZEB renovation requirements considering the different scenarios defined for the building used as a case study in the two pairs of cities of Portugal and Spain previously selected.

- Analyse the results from the perspective of the following research questions:

a) Are the nZEB requirements for the thermal characteristics of the renovated envelope equivalent in Portugal and Spain for colder and warmer cities? If not, what implications do these differences have in terms of reduction of $\mathrm{CO}_{2}$ emissions?

b) What thermal characteristics of the envelope allow to comply with the nZEB renovation requirements? Is it necessary to additionally improve the active systems to achieve nZEB requirements or is the improvement of the envelope enough?

c) What are the specific conclusions of these nZEB renovation requirements for this building typology?

\section{Theory and calculation}

\subsection{Requirements for $n Z E B$ renovation: European context, Portugal and Spain}

The first European directive that regulated energy saving in buildings was Directive 89/106/EEC that stipulated that the construction works and its heating, cooling and ventilation installations should be designed and built in such a way that the amount of energy required in use should be low, having regard to the climatic conditions of the location and the occupants [29]. Then, Directive 93/76/EEC pointed out that the residential and tertiary sectors accounted for nearly $40 \%$ of final energy consumption in the Community and were expanding, a trend which was bound to increase their energy consumption and hence also their carbon dioxide emissions [30], requiring MS to develop, implement and report on programs in the field of energy efficiency in the buildings sector.

The programs were unequally developed by the different MS, and the first EPBD, Directive 2002/91/CE, was approved to address this problem requiring that the MS strengthened their building regulations, introducing the concept of energy performance certification of buildings, and establishing the need of the inspection of boilers, and air conditioning systems [31].

Directive 2009/28/EC promoted the use of energy from renewable sources, requiring that $20 \%$ of the energy consumed within the European Union was renewable. This policy later became part of the EU 2020 Energy Strategy dated November 10, 2010. According to the directive, by December 31, 2014, MS had the obligation to require the use of minimum levels of energy from renewable sources in new buildings and in existing buildings that are subject to major renovation in their building regulations and codes or by other means with equivalent effect [32].

In 2010, the 2002 EPBD was revised and Directive 2010/31/EU was approved, being the first recast of the original EPBD. According to it: a) For buildings offered for sale or rent, the energy performance certificates should be stated in the advertisements;

b) MS should lay down the necessary measures to establish inspection schemes for heating and air-conditioning systems or take measures with equivalent impact;

c) All new buildings should be nearly zero energy buildings after December 31, 2020. The same applies to all new public buildings after $31{ }^{\text {st }}$ December 2018;

d) MS should set minimum energy performance requirements for new buildings, for buildings subject to major renovation, as well as for the replacement or retrofit of building elements; and

e) MS should draw up lists of national financial measures and instruments to improve the energy efficiency of buildings [33,34].

This directive was partially amended by Directive $2012 / 27$ /EU on energy efficiency, which added that MS should establish a long-term strategy for mobilizing investment in the renovation of the national stock of residential and commercial buildings, both public and private, and that the total floor area of heated and/or cooled buildings owned and occupied by its central government should be renovated each year at a minimum rate of $3 \%$ to meet at least a minimum energy performance requirements.

A recent EPBD, Directive 2018/844, amends directives 2010/31/EU and 2012/27/EU. According to it, each MS shall establish a stronger long-term renovation strategy to support the renovation of the national stock of residential and non-residential buildings, both public and private, into a highly energy efficient and decarbonized building stock by 2050, facilitating the cost-effective transformation of existing buildings into nZEBs, with indicative milestones for 2030, 2040 and 2050, measurable progress indicators and with a solid financial component [1]. EU countries had until March 10, 2020 to write the new and revised provisions into national law.

Recommendations on how EU countries should implement the revised building renovation aspects of the EPBD were published in July 2019 [6] in response to requests for clarification from MS. In this document, it is specified that different renovation depths have been developed in the context of the EU Building Stock Observatory on the basis of primary energy savings:

$$
\begin{aligned}
& \text { - light (less than 30\%); } \\
& \text { - medium (between 30\% and 60\%); and } \\
& \text { - deep (over 60\%). }
\end{aligned}
$$

The nZEB level for renovations is not defined in terms of a specific primary energy saving threshold, but according to official national nZEB renovation definitions. Therefore, in this paper, the official national definitions of nZEBs will be considered for the study of their requirements models.

Currently, Portugal does not have a specific definition of nZEB for renovation, but the same requirements must be met to achieve a nZEB for the cases of new and existing buildings. In Spain a specific definition of nZEB for renovation was approved in December 2019. In none of these two countries, complying with nZEB requirements is mandatory for the renovation of existing buildings, although it is encouraged. Fig. 1 shows a timeline of European directives and its relation with national regulations in Portugal and Spain.

\subsubsection{Portuguese regulations}

In 1990, the Decree-Law 40/90 [35] was issued, establishing the first Regulation in Portugal that dealt with the thermal behavior of buildings. The amount of energy needed to obtain thermal comfort and buildings thermal parameters had to comply with regulatory requirements. In 2006, the Decree-Law 80/2006 [36] was published, which transposed Directive 2002/91/EC [31] (first version of the EPBD) into Portuguese regulations. Later, the Decree-Law 118/2013 [37] replaced the former one, fulfilling the requirements of the 2010 EPBD recast [2] and it is 


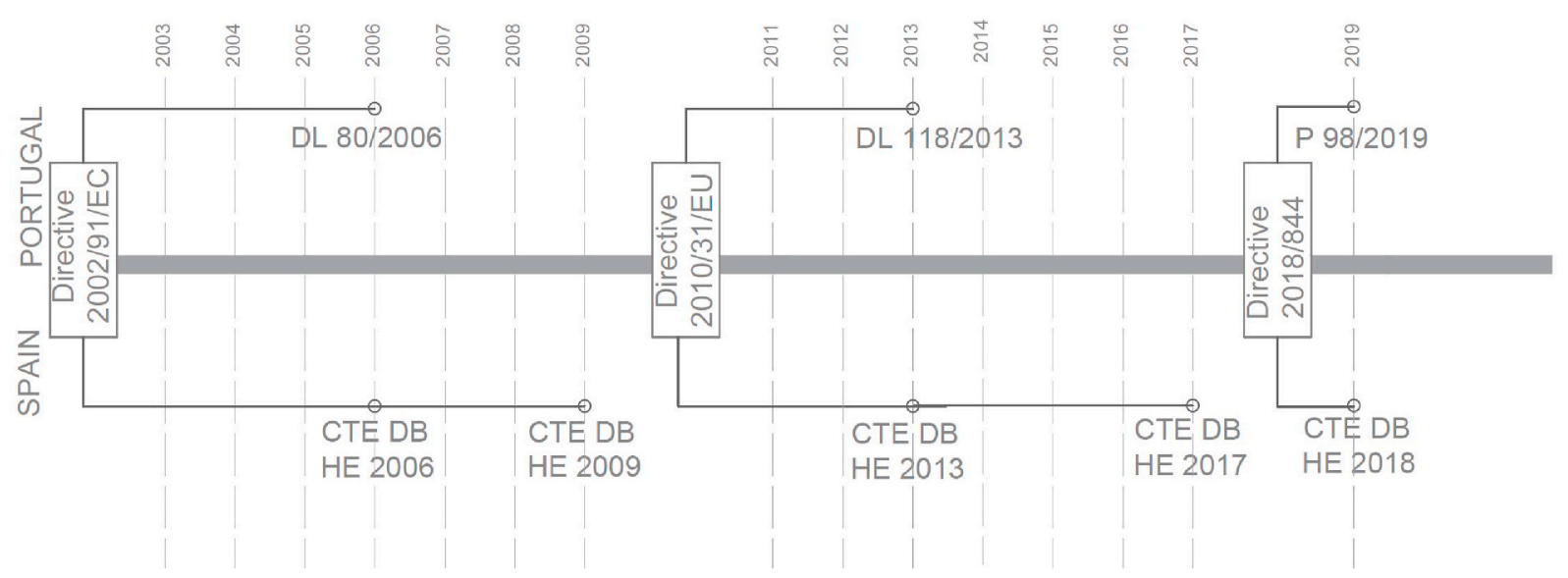

Fig. 1. Timeline of European directives and national regulations in Portugal and Spain.

currently in force. It introduced the nZEB concept in Portuguese regulations adopting the same definition of the EPBD 2010 recast.

The base document has several complementary ones, through Ordinances, Despachos and Portarias. By Portaria $\mathrm{N}^{\circ} 349-\mathrm{B} / 2013$ [38], the dwellings energy requirements are defined (update in 2015 by Portaria $\left.\mathrm{N}^{\circ} 379-\mathrm{A} / 2015\right)$. The calculation method is established in Despacho 15, $793 / 2013$, currently in force. Portaria $N^{\circ} 98 / 2019$ [39] has recently modified the Portaria $\mathrm{N}^{\circ} 349-\mathrm{B} / 2013$ with respect to the requirements for nZEBs, and is currently in force. Buildings have to comply with a maximum allowable value of annual nominal needs of primary energy $\left(\mathrm{N}_{\mathrm{t}}\right)$, which takes into consideration the maximum allowable values of the annual nominal needs of final energy for heating $\left(\mathrm{N}_{\mathrm{i}}\right)$ and for cooling $\left(\mathrm{N}_{\mathrm{v}}\right)$, in addition to the final energy needed for DHW. Portuguese regulation defines $\mathrm{Ni}$ and $\mathrm{Nv}$ according to EN ISO 13790:2011.

All new buildings built from December 31, 2020 on have to be nZEBs. Major renovations have their own compulsory requirements (Portaria 297/2019) [40], but if a nZEB renovation is aimed for, then the same requirements as for new nZEBs must be met. A dwelling will be considered a nZEB if it has an annual nominal final energy need for heating equal to or less than $75 \%$ of its maximum allowable value $\left(\mathrm{N}_{\mathrm{i}}\right)$, a nominal value of estimated primary energy need of $50 \%$ or less of its maximum allowable value $\left(\mathrm{N}_{\mathrm{t}}\right)$ and the use of renewable systems meets at least $50 \%$ of annual primary energy needs. Table A1 in Appendix A summarizes the nZEB and major renovation main requirements.

There are several available calculation tools to obtain the calculated and maximum values of the building's energy needs. In this paper, the spreadsheet provided by the Platform for Energy Efficiency in Buildings (P3E) of the Institute for Research and Technological Development in Construction, Energy, Environment and Sustainability (Itecons) [41] is used. The calculation is done for each dwelling of a building.

\subsubsection{Spanish regulations}

In 1979 the first regulation on energy performance of new buildings was approved, NBE CT 79 [42]. This regulation was substituted by Royal Decree 314/2006 that approved the Buildings Technical Code (in Spanish Código Técnico de la Edificación, CTE). The energy performance of buildings is regulated by the Basic Document on Energy Saving (DB-HE) within the CTE. In 2007, the Royale Decree RD 47/2007 approved the basic procedure for the energy certification of new buildings and major renovations.

In 2013, the Order FOM/1635/2013, of September 10, updated the Basic Document DB-HE of the CTE, and the Royale Decree RD 235/2013 on energy certification amended the previous procedure and extended the application scope to existing buildings that are sold or rented. Another important regulation was published this year, RD August 2013 to promote the refurbishment of buildings.

In 2017, the Order FOM/588/2017 updated the Basic Document DB-
HE of the CTE, adding the definition of nZEB as the building fulfilling the requirements for new buildings included in the 2013 regulation.

A Draft Royal Decree modifying the Basic Document DB-HE of the CTE was made public by the Ministry of Public Works in 2018 [43], and recently, in December 2019, was definitively published [44]. This regulation, defines more restrictive requirements for nZEBs, which will be compulsory for new buildings. Major renovations have other compulsory requirements, but if a nZEB renovation is aimed for, which is not mandatory, then the same energy consumption requirements as for new nZEBs must be met, along with major renovations requirements. Therefore, the requirements for nZEB renovation can be summarized as follows (Table A1 in Appendix A summarizes the nZEB and major renovation main requirements):

a) A maximum U-value is set for each element of the envelope which is added, replaced or modified. The $\mathrm{U}$-value requirements are the same for new buildings and major renovations.

The envelope global heat transfer coefficient $\mathrm{K}$ must be less than a limit value $\mathrm{K}_{\text {limit }}\left(\mathrm{W} / \mathrm{m}^{2} \mathrm{~K}\right.$ ) (Table $\mathrm{A} 1$ in Appendix $\mathrm{A}$ ). This value depends on the U-values of the envelope elements and thermal bridges and it is a concept quite similar to the heat transfer coefficient $\mathrm{H}_{\mathrm{d}}$ of ISO 14683:2017 [45], but divided by the exchange area [46]. The maximum allowable K-value depends on the climate zone and the compactness of the building.

b) The value of the solar control of windows will be lower than $2 \mathrm{~kW} \mathrm{~h} /$ $\mathrm{m}^{2}$.month for the month of July for households. The solar control is the ratio between the solar gains in July of all windows of the envelope with their solar protections activated, and the useful floor area of the building.

c) The accepted permeability of the windows of the envelope are those corresponding to classes 2 or 3 depending on the climatic zone, as defined in EN 12207:2017.

d) The interstitial condensations in the thermal envelope will be such that they do not produce a significant decrease in its thermal performance or pose a risk of degradation or loss of its service life.

e) Non-renewable primary energy and total primary energy consumptions are limited by a fixed value depending on the climatic zone (Table A1 in Appendix A).

f) At least $60 \%$ of the energy demand for DHW has to be obtained from renewable sources, with local origin or close to the building (Table A1 in Appendix A).

To verify the compliance with Spanish regulation a simulation tool called HULC (Herramienta Unificada Lider-Calener) must be used, which is the official tool in Spain to check the compliance with the recent regulation. A new version of this tool was published in January 2020, to check compliance with the Royale Decree publishing the basic 
document DB-HE 2018.

\subsection{Climate zones}

In Spain, the basic document DB-HE establishes the climate zoning so that there is a total of 17 zones, 12 of them being peninsular and 5 corresponding to the Canary Islands. The climate zones are A3, A4, B3, B4, C1, C2, C3, C4, D1, D2, D3, and E1 for peninsular communities, and $\alpha 1, \alpha 2, \alpha 3, \mathrm{~A} 2$, and B2 for the Canary Islands [47]. The 12 peninsular zones are composed by a letter to identify the winter conditions (ranging from A to E), and a number to identify the summer conditions (from 1 to 4).

The basic document DB-HE establishes for each of the climate zones a «reference climate», which defines the external calculation requirements for a standard year through a series of parameters: dry temperature $\left({ }^{\circ} \mathrm{C}\right)$, relative humidity $(\%)$, Solar global irradiance on a horizontal plane $\left(\mathrm{W} / \mathrm{m}^{2}\right)$, representative of a climate zone [47].

In Portugal, winter climate zones are defined based on the number of degree-days (DD) for a baseline temperature of $18^{\circ}$, corresponding to the heating season [48]. The heating season is defined as the sum of the periods of 10 days, for which the daily average of outdoor temperature is less than $15^{\circ} \mathrm{C}$. These periods of 10 days must be comprised between the 1 st October and the 31st May [49]. The winter climate zones are:

\footnotetext{
- Zone I1: DD $\leq 1300$;

- Zone I2: $1300<\mathrm{DD} \leq 1800$;

- Zone I3: DD > 1800 .
}

The summer climate zones are defined according to the average external temperature @ext corresponding to the conventional cooling station June-September:

- Zone V1: @ext $\leq 20^{\circ} \mathrm{C}$;

- Zone V2: $20^{\circ} \mathrm{C}<$ Oext $\leq 22{ }^{\circ} \mathrm{C}$;

- Zone V3: @ext $>22{ }^{\circ} \mathrm{C}$.

Whereas climate zones in Spain are defined depending on temperature, humidity and solar irradiance, in Portugal they depend on temperature-related parameters, such as degree-days and average temperature [49].

To be able to compare the results using the local tools, climate zones in Portugal and Spain as similar as possible with respect to climate conditions and geographical situations were searched for. Two pairs of cities were chosen (Table 1), one pair representing cold cities in

Table 1

Data about cities chosen as cases of study.

\begin{tabular}{|c|c|c|}
\hline Conditions & Portugal & Spain \\
\hline City & Guarda & Teruel \\
\hline Latitude & 40.53 & 40.34 \\
\hline Altitude & $1056 \mathrm{~m}$ & $995 \mathrm{~m}$ \\
\hline Distance to the sea & $>5 \mathrm{~km}$ & $>5 \mathrm{~km}$ \\
\hline $\begin{array}{l}\text { Degree days } 18{ }^{\circ} \mathrm{C} \text { (according to } \\
\text { Portugal regulation [49]) }\end{array}$ & $\begin{array}{l}2263 \\
{[6]}\end{array}$ & $\begin{array}{l}2470 \text { (estimated by authors } \\
\text { according to Ref. [48] with data } \\
\text { from Ref. [50]) }\end{array}$ \\
\hline $\begin{array}{l}\text { Average temperature } \\
\text { June-September }\end{array}$ & $20^{\circ} \mathrm{C}$ & $20.21^{\circ} \mathrm{C}$ \\
\hline City & Faro & Cádiz \\
\hline Latitude & 37.01 & 36.53 \\
\hline Altitude & $12 \mathrm{~m}$ & $0 \mathrm{~m}$ \\
\hline Distance to the sea & $<4 \mathrm{~km}$ & $<4 \mathrm{~km}$ \\
\hline $\begin{array}{l}\text { Degree days } 18{ }^{\circ} \mathrm{C} \text { (calculated } \\
\text { according to Portugal regulation } \\
\text { [49]) }\end{array}$ & $744[6]$ & $\begin{array}{l}440 \text { (estimated by authors } \\
\text { according to Ref. [38] with data } \\
\text { from Ref. [42]) }\end{array}$ \\
\hline $\begin{array}{l}\text { Average temperature } \\
\text { June-September }\end{array}$ & $23.1^{\circ} \mathrm{C}$ & $22.82{ }^{\circ} \mathrm{C}$ \\
\hline
\end{tabular}

Southern Europe and the other pair representing warm ones. The degree-days for a baseline temperature of $18{ }^{\circ} \mathrm{C}$ for the two cities of Spain were estimated and checked that they would belong to the same winter zone as the Portuguese ones according to the Portuguese system.

\subsection{Typical residential building to be renovated in Portugal and Spain}

The decades with a highest percentage of buildings constructed in Portugal were 1971-1980 (16.6\%), 1981-1990 (16.4\%) and 1961-1970 (11.5\%) [22]. In the case of Spain they were 1971-1980 (18.1\%), 1991-2000 (16.1\%) and 1961-1970 (13.5\%) [21,23]. In the two countries the period 1961-1980 is included among the decades with the highest buildings construction growth. Additionally, as already pointed out in the introduction, the years 1961-1980 are considered as a period where buildings had a poor energy performance in these two countries, and both residential building stocks present significantly close characteristics. For these reasons, the typical residential building to be used as a case study is selected analyzing the characteristics of the buildings of this period.

Most of the multi-family buildings built between 1971 and 1980 in Portugal have 2 floors (33.7\%) or 3 floors (19.4\%), and the dwellings have a useful floor area of $80-99 \mathrm{~m}^{2}(19.9 \%)$ [22]. In Spain, most of the buildings built between 1961 and 1980 have 3 floors and the useful floor area of the dwellings is $76-90 \mathrm{~m}^{2}$ [23]. Windows occupy $17-23 \%$ of the façades [51]. Our case study has 3 floors and $84 \mathrm{~m}^{2}$ of useful floor area per dwelling, as shown in Table 2.

According to Ref. [22] the majority of the Portuguese multi-family buildings built between 1971 and 1980 have reinforced concrete structures $(54.15 \%)$, rendered and painted façade (88\%), and pitched roofs with ceramic tiles (93.4\%). The construction data of the Portuguese buildings are obtained from an official report on the thermal performance of buildings and the application of the Portuguese building thermal regulation [52] and contrasted with other sources [27,53,54]. For the case of Spain the data from the TABULA EPISCOPE project [55] is used. According to this project, contrasted with other sources [15,51, 56-59], the typical façade of the building built between 1960 and 1980 in Spain is double-brick walls with air chamber, flat roof and pitched roof, and windows with single glass and aluminum frame. The closest construction solutions in the two countries are selected for our case study among the most typical ones, and shown in Table 2.

According to Ref. [60] in Portugal electricity is the main energy source for heating, followed by gas, LPG (butane) and wood biomass. The main energy source for heating DHW is gas, followed by LPG (butane). Space cooling is provided solely by electricity.

In Spain, heating and cooling installations are different according to the climatic zone. According to Ref. [61,62], natural gas is the fuel used in most dwellings. However, in the north and south, the most common fuel to multi-familiar buildings is gas fuel for individual heating, and in the continental zone the most common is oil fuel products in individual heating [63].

The heating, cooling and DHW solutions used in our case study are shown in Table 2.

\subsection{Calculations}

\subsubsection{Models in the software tools}

Fig. 2 shows the case study considered to simulate in Spain and Portugal, and Table 2 showed its construction solutions characteristics.

The case study is a three-story building with plan dimensions of $22 \times$ $8 \mathrm{~m}^{2}$, with two dwellings per floor and a staircase. North and South façades have $6 \mathrm{~m}^{2}$ of windows per dwelling and East and West façades have no windows. Typically, these dwellings benefit from crossventilation.

This paper studies the original state and some renovation scenarios, which include combinations of different solutions for envelope refurbishment (coded with a number) and systems improvements (coded 
Table 2

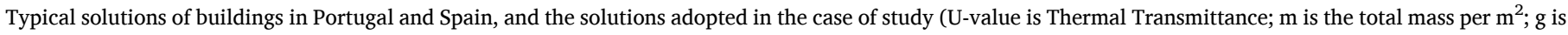
the Solar Factor of the glass).

\begin{tabular}{|c|c|c|c|}
\hline & Portugal & Spain & Case of study (original state) \\
\hline \multicolumn{4}{|l|}{ Characteristics } \\
\hline \multirow[t]{3}{*}{$\begin{array}{l}\text { Year of } \\
\text { construction }\end{array}$} & $1971-1980(16.6 \%)$ & 1971-1980 (18.1\%), & \\
\hline & 1981-1990 (16.4\%) & $1991-2000(16.1 \%)$ & \\
\hline & 1961-1970 (11.5\%) [22] & $1961-1970(13.5 \%)[23]$ & \\
\hline Floors & $\begin{array}{l}2-3 \text { floors } \\
{[22]}\end{array}$ & 3 floors [23] & 3 floors \\
\hline Area & $80-99 \mathrm{~m}^{2}[22]$ & $76-90 \mathrm{~m}^{2}[23]$ & $84 \mathrm{~m}^{2}$ per dwelling \\
\hline \multicolumn{4}{|c|}{ Construction solutions } \\
\hline Façade & $\begin{array}{l}\text { Double-brick walls, inner air chamber. } \\
\text { U-value }=1.1 \mathrm{~W} / \mathrm{m}^{2} \mathrm{~K}[27,52-54]\end{array}$ & $\begin{array}{l}\text { Double-brick walls, inner air chamber. } \\
\text { U-value }=1.33-1.43 \mathrm{~W} / \mathrm{m}^{2} \mathrm{~K}[15,51,55-59]\end{array}$ & $\begin{array}{l}\text { Double-brick walls, inner air chamber. } \\
\text { U-value }=1.33 \mathrm{~W} / \mathrm{m}^{2} \mathrm{~K}, \mathrm{~m}=181 \mathrm{~kg} / \mathrm{m}^{2}\end{array}$ \\
\hline Roof & $\begin{array}{l}\text { Pitched roof with ceramic tiles. } \\
\text { U-value }=2.63 \mathrm{~W} / \mathrm{m}^{2} \mathrm{~K}[27,52-54]\end{array}$ & $\begin{array}{l}\text { Flat roof and pitched roof with ceramic tiles. } \\
\text { U-value }=2.33 \mathrm{~W} / \mathrm{m}^{2} \mathrm{~K}[15,51,55-59]\end{array}$ & $\begin{array}{l}\text { Pitched roof with ceramic tiles. } \\
\text { U-value }=2.63 \mathrm{~W} / \mathrm{m}^{2} \mathrm{~K}, \mathrm{~m}=323 \mathrm{~kg} / \mathrm{m}^{2}\end{array}$ \\
\hline Window & $\begin{array}{l}\text { Metal frame and single glass, with roller blind } \\
\text { shutter. } \\
\text { U-value }=5.7 \mathrm{~W} / \mathrm{m}^{2} \mathrm{~K} \mathrm{~g}=0.87[27,52-54]\end{array}$ & $\begin{array}{l}\text { Metal frame and single glass, with roller blind } \\
\text { shutter. } \\
\text { U-value }=5.7 \mathrm{~W} / \mathrm{m}^{2} \mathrm{~K} \mathrm{~g}=0.80-0.85[15,51 \text {, } \\
55-59]\end{array}$ & $\begin{array}{l}\text { Metal frame and single glass, with roller blind } \\
\text { shutter. } \\
\text { U-value }=5.7 \mathrm{~W} / \mathrm{m}^{2} \mathrm{~K}, \mathrm{~g}=0.85\end{array}$ \\
\hline \multicolumn{4}{|l|}{ Systems } \\
\hline DHW & Gas boiler or GLP butane boiler $[53,54,60]$ & Gas boiler or electricity heaters $[59,61-63]$ & Gas boiler or electricity heaters \\
\hline Heating & Electricity or gas boiler $[53,54,60]$ & Gas boiler or electricity heaters $[59,61-63]$ & Gas boiler or electricity heaters \\
\hline Cooling & None or electricity $[53,54,60]$ & None or electricity $[59,61-63]$ & None \\
\hline
\end{tabular}

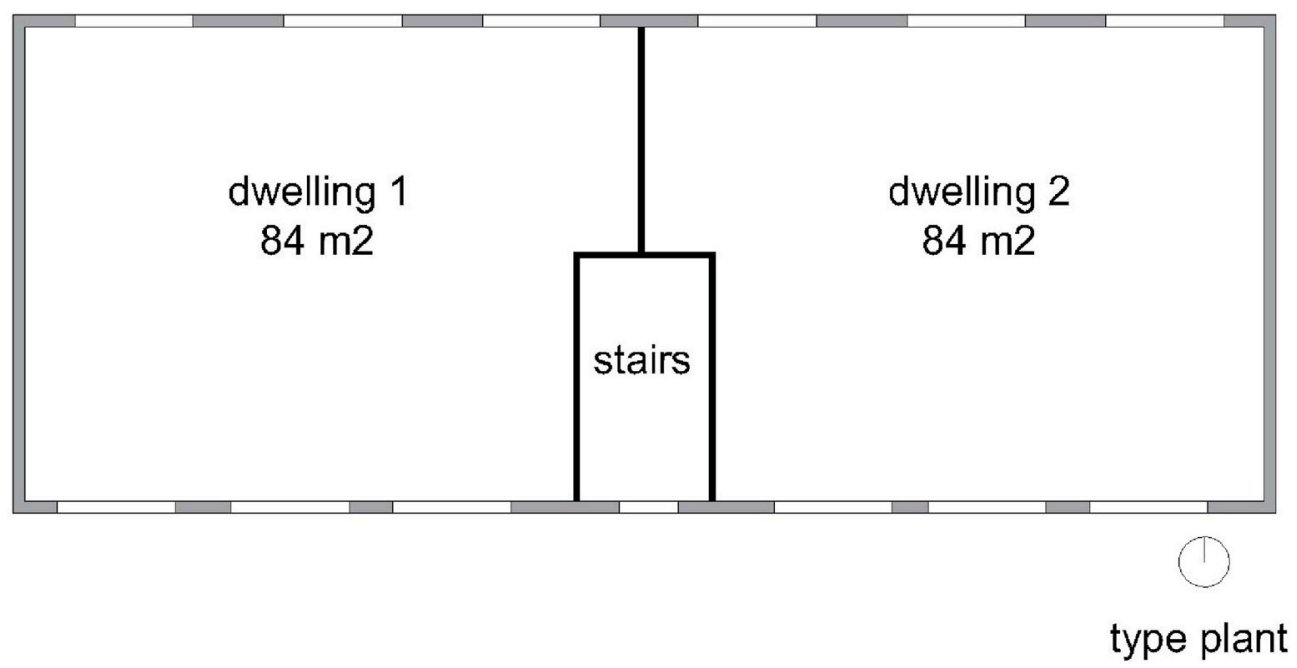

Fig. 2. Type plant of the case study.

with a letter). With the objective of comparison, different levels are established based on the regulations of each country. The solutions for the envelope refurbishment are (Tables 3 and 4):

- Solution 1. Original state.

- Solution 2. U-values for major renovation according to the regulations of each country. In the case of Portugal, the Portaria 297/2019 is used. In the case of Spain the U-value requirements are the same for new buildings and major renovations. In Portugal, the requirements for façades are U-value $\leq 1.70 \mathrm{~W} / \mathrm{m}^{2} \mathrm{~K}$ for Faro and $\mathrm{U}$ value $\leq 1.40 \mathrm{~W} / \mathrm{m}^{2} \mathrm{~K}$ for Guarda. However, these U-values are higher than those of the original state. For this reason, for the envelope refurbishment solution 2 of Portugal the façade does not have insulation, and the U-value used for the façade is that of the original state.

- Solution 3. In Portugal, the requirements for new buildings (before nZEB requirement were compulsory) according to Portaria 379-A/ 2015 are used [38]. In Spain, the requirements used are the suggested U-values for new buildings in DB HE 2018 [43,44].

- Solution 4. High refurbishment. Low U-values are used, considering insulation thicknesses between 18 and $20 \mathrm{~cm}$ in the envelope and triple glazing [64-66]. Although unusual in Portugal and Spain, very low U-values are considered to serve as a reference for high refurbishment.

The solutions for the improvement of the systems include:

- Solution A: Old gas boiler for heating and DHW. Efficiency: heating 75\% and DHW 81\% [67].

- Solution B: Old electricity system for heating -electrical heater- and DHW -water heater-. Efficiency: 99\% [65].

- Solution C: new gas condensing boiler for heating and DHW, boiler efficiency $\eta=100 \%[60,61,69]$, and solar panels to DHW.

- Solution D: new electricity system -heat pump-for heat and DHW with solar panels for DHW. Coefficient of Performance (COP): 4,5 $[68,69]$.

Simulations were undertaken in the two pairs of cities located in the two countries. The warmer Portuguese city is Faro $(\mathrm{I} 1+\mathrm{V} 3)$ and the Spanish one is Cádiz (A3). The colder Portuguese city is Guarda (I3+V2) and the Spanish one is Teruel (D2). The number of people per dwelling 
Table 3

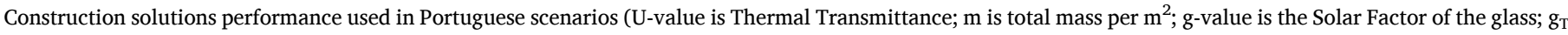
is the global glazing Solar Factor with all solar protection devices, permanent or fully activated).

\begin{tabular}{|c|c|c|c|c|c|}
\hline \multirow[t]{2}{*}{ PORTUGAL } & & \multirow{2}{*}{$\frac{\text { Solution } 1}{\text { ORIGINAL STATE }}$} & \multirow{2}{*}{$\begin{array}{l}\text { Solution } 2 \\
\text { Requirements to major } \\
\text { renovations }\end{array}$} & \multirow{2}{*}{$\frac{\text { Solution } 3}{\text { Requirements to new buildings }}$} & \multirow{2}{*}{$\frac{\text { Solution } 4}{\text { High Refurbishment }}$} \\
\hline & & & & & \\
\hline Façade & $\begin{array}{l}\text { FARO } \\
\text { GUARDA }\end{array}$ & $\mathrm{U}$-value $=1.33 \mathrm{~W} / \mathrm{m}^{2} \mathrm{~K}, \mathrm{~m}=181 \mathrm{~kg} / \mathrm{m}^{2}$ & $\begin{aligned} \mathrm{U} \text {-value } & =1.33 \mathrm{~W} / \mathrm{m}^{2} \mathrm{~K} \\
\mathrm{U} \text {-value } & =1.33 \mathrm{~W} / \mathrm{m}^{2} \mathrm{~K}\end{aligned}$ & $\begin{aligned} \mathrm{U} \text {-value } & =0.50 \mathrm{~W} / \mathrm{m}^{2} \mathrm{~K} \\
\mathrm{U} \text {-value } & =0.35 \mathrm{~W} / \mathrm{m}^{2} \mathrm{~K}\end{aligned}$ & $\begin{array}{l}\mathrm{U} \text {-value }=0.15 \mathrm{~W} / \mathrm{m}^{2} \mathrm{~K} \\
\mathrm{U} \text {-value }=0.15 \mathrm{~W} / \mathrm{m}^{2} \mathrm{~K}\end{array}$ \\
\hline Roof & $\begin{array}{l}\text { FARO } \\
\text { GUARDA }\end{array}$ & U-value $=2.63 \mathrm{~W} / \mathrm{m}^{2} \mathrm{~K}, \mathrm{~m}=323 \mathrm{~kg} / \mathrm{m}^{2}$ & $\begin{aligned} \mathrm{U} \text {-value } & =0.80 \mathrm{~W} / \mathrm{m}^{2} \mathrm{~K} \\
\mathrm{U} \text {-value } & =0.60 \mathrm{~W} / \mathrm{m}^{2} \mathrm{~K}\end{aligned}$ & $\begin{aligned} \mathrm{U} \text {-value } & =0.40 \mathrm{~W} / \mathrm{m}^{2} \mathrm{~K} \\
\mathrm{U} \text {-value } & =0.30 \mathrm{~W} / \mathrm{m}^{2} \mathrm{~K}\end{aligned}$ & $\begin{aligned} \mathrm{U} \text {-value } & =0.14 \mathrm{~W} / \mathrm{m}^{2} \mathrm{~K} \\
\mathrm{U} \text {-value } & =0.14 \mathrm{~W} / \mathrm{m}^{2} \mathrm{~K}\end{aligned}$ \\
\hline Ground floor & $\begin{array}{l}\text { FARO } \\
\text { GUARDA }\end{array}$ & $\begin{array}{l}\mathrm{U} \text {-value }=4.11 \mathrm{~W} / \mathrm{m}^{2} \mathrm{~K} \\
\mathrm{M}=200 \mathrm{~kg} / \mathrm{m}^{2}\end{array}$ & $\begin{aligned} \mathrm{U} \text {-value } & =1.00 \mathrm{~W} / \mathrm{m}^{2} \mathrm{~K} \\
\mathrm{U} \text {-value } & =0.80 \mathrm{~W} / \mathrm{m}^{2} \mathrm{~K}\end{aligned}$ & $\begin{aligned} \mathrm{U} \text {-value } & =0.50 \mathrm{~W} / \mathrm{m}^{2} \mathrm{~K} \\
\mathrm{U} \text {-value } & =0.50 \mathrm{~W} / \mathrm{m}^{2} \mathrm{~K}\end{aligned}$ & $\begin{aligned} \mathrm{U} \text {-value } & =0.30 \mathrm{~W} / \mathrm{m}^{2} \mathrm{~K} \\
\mathrm{U} \text {-value } & =0.30 \mathrm{~W} / \mathrm{m}^{2} \mathrm{~K}\end{aligned}$ \\
\hline Windows & GUARDA & $\begin{array}{l}\mathrm{U} \text {-value }=5.7 \mathrm{~W} / \mathrm{m}^{2} \mathrm{~K} \text { with shutter box } \\
\text { g-value }=0.85\end{array}$ & $\begin{array}{l}\mathrm{U} \text {-value }=4.50 \mathrm{~W} / \mathrm{m}^{2} \mathrm{~K}, \mathrm{~g}_{\mathrm{T}^{-}} \\
\text {value }=0.3, \\
\mathrm{~g} \text {-value }=0.7 \\
\mathrm{U} \text {-value }=4.00 \mathrm{~W} / \mathrm{m}^{2} \mathrm{~K}, \mathrm{~g}_{\mathrm{T}^{-}} \\
\text {value }=0.35, \\
\mathrm{~g} \text {-value }=0.7\end{array}$ & $\begin{array}{l}\mathrm{U} \text {-value }=2.80 \mathrm{~W} / \mathrm{m}^{2} \mathrm{~K}, \mathrm{~g}_{\mathrm{T}^{-}} \\
\text {value }=0.5, \\
\mathrm{~g} \text {-value }=0.7 \\
\mathrm{U} \text {-value }=2.20 \mathrm{~W} / \mathrm{m}^{2} \mathrm{~K}, \mathrm{~g}_{\mathrm{T}^{-}} \\
\text {value }=0.56 \\
\mathrm{~g} \text {-value }=0.7\end{array}$ & $\begin{array}{l}\mathrm{U} \text {-value }=1.00 \mathrm{~W} / \mathrm{m}^{2} \mathrm{~K}, \mathrm{~g}_{\mathrm{T}} \\
\text { value }=0.1, \\
\mathrm{~g} \text {-value }=0.7 \\
\mathrm{U} \text {-value }=1.00 \mathrm{~W} / \mathrm{m}^{2} \mathrm{~K}, \mathrm{~g}_{\mathrm{T}} \\
\text { value }=0.1, \\
\mathrm{~g} \text {-value }=0.7\end{array}$ \\
\hline $\begin{array}{l}\text { Wall stairs- } \\
\text { dwellings }\end{array}$ & $\begin{array}{l}\text { FARO } \\
\text { GUARDA }\end{array}$ & $\begin{array}{l}\text { U-value }=2.64 \mathrm{~W} / \mathrm{m}^{2} \mathrm{~K} \mathrm{~m}=101.80 \mathrm{~kg} / \\
\mathrm{m}^{2}\end{array}$ & $\begin{aligned} \mathrm{U} \text {-value } & =1.70 \mathrm{~W} / \mathrm{m}^{2} \mathrm{~K} \\
\mathrm{U} \text {-value } & =1.40 \mathrm{~W} / \mathrm{m}^{2} \mathrm{~K}\end{aligned}$ & $\begin{aligned} \mathrm{U} \text {-value } & =0.80 \mathrm{~W} / \mathrm{m}^{2} \mathrm{~K} \\
\mathrm{U} \text {-value } & =0.60 \mathrm{~W} / \mathrm{m}^{2} \mathrm{~K}\end{aligned}$ & $\mathrm{U}$-value $=0.20 \mathrm{~W} / \mathrm{m}^{2} \mathrm{~K}$ \\
\hline
\end{tabular}

Table 4

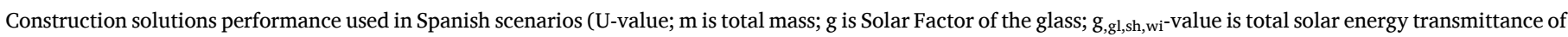
the glazing with activated mobile shading devices).

\begin{tabular}{|c|c|c|c|c|c|}
\hline \multirow[t]{2}{*}{ SPAIN } & & \multirow{2}{*}{$\frac{\text { Solution } 1}{\text { ORIGINAL STATE }}$} & \multirow{2}{*}{$\begin{array}{l}\text { Solution } 2 \\
\text { Requirements for major } \\
\text { renovations }\end{array}$} & \multirow{2}{*}{$\begin{array}{l}\text { Solution } 3 \\
\begin{array}{l}\text { Suggested values for new } \\
\text { buildings }\end{array}\end{array}$} & \multirow{2}{*}{$\frac{\text { Solution } 4}{\text { High Refurbishment }}$} \\
\hline & & & & & \\
\hline Façade & $\begin{array}{l}\text { CADIZ } \\
\text { TERUEL }\end{array}$ & $\begin{array}{l}\mathrm{U} \text {-value }=1.33 \mathrm{~W} / \mathrm{m}^{2} \mathrm{~K}, \mathrm{~m}=181 \mathrm{~kg} / \\
\mathrm{m}^{2}\end{array}$ & $\begin{array}{l}\mathrm{U} \text {-value }=0.70 \mathrm{~W} / \mathrm{m}^{2} \mathrm{~K} \\
\mathrm{U} \text {-value }=0.41 \mathrm{~W} / \mathrm{m}^{2} \mathrm{~K}\end{array}$ & $\begin{array}{l}\mathrm{U} \text {-value }=0.50 \mathrm{~W} / \mathrm{m}^{2} \mathrm{~K} \\
\mathrm{U} \text {-value }=0.27 \mathrm{~W} / \mathrm{m}^{2} \mathrm{~K}\end{array}$ & $\begin{aligned} \mathrm{U} \text {-value } & =0.15 \mathrm{~W} / \mathrm{m}^{2} \mathrm{~K} \\
\mathrm{U} \text {-value } & =0.15 \mathrm{~W} / \mathrm{m}^{2} \mathrm{~K}\end{aligned}$ \\
\hline Roof & $\begin{array}{l}\text { CADIZ } \\
\text { TERUEL }\end{array}$ & $\begin{array}{l}\text { U-value }=2.63 \mathrm{~W} / \mathrm{m}^{2} \mathrm{~K}, \mathrm{~m}=323 \mathrm{~kg} / \\
\mathrm{m}^{2}\end{array}$ & $\begin{array}{l}\mathrm{U} \text {-value }=0.50 \mathrm{~W} / \mathrm{m}^{2} \mathrm{~K} \\
\mathrm{U} \text {-value }=0.35 \mathrm{~W} / \mathrm{m}^{2} \mathrm{~K}\end{array}$ & $\begin{array}{l}\mathrm{U} \text {-value }=0.44 \mathrm{~W} / \mathrm{m}^{2} \mathrm{~K} \\
\mathrm{U} \text {-value }=0.22 \mathrm{~W} / \mathrm{m}^{2} \mathrm{~K}\end{array}$ & $\begin{array}{l}\mathrm{U} \text {-value }=0.14 \mathrm{~W} / \mathrm{m}^{2} \mathrm{~K} \\
\mathrm{U} \text {-value }=0.14 \mathrm{~W} / \mathrm{m}^{2} \mathrm{~K}\end{array}$ \\
\hline Ground floor & $\begin{array}{l}\text { CADIZ } \\
\text { TERUEL }\end{array}$ & $\begin{array}{l}\mathrm{U} \text {-value }=4.11 \mathrm{~W} / \mathrm{m}^{2} \mathrm{~K}, \mathrm{~m}=200 \mathrm{~kg} / \\
\mathrm{m}^{2}\end{array}$ & $\begin{array}{l}\mathrm{U} \text {-value }=0.80 \mathrm{~W} / \mathrm{m}^{2} \mathrm{~K} \\
\mathrm{U} \text {-value }=0.65 \mathrm{~W} / \mathrm{m}^{2} \mathrm{~K}\end{array}$ & $\begin{array}{l}\mathrm{U} \text {-value }=0.80 \mathrm{~W} / \mathrm{m}^{2} \mathrm{~K} \\
\mathrm{U} \text {-value }=0.48 \mathrm{~W} / \mathrm{m}^{2} \mathrm{~K}\end{array}$ & $\begin{aligned} \mathrm{U} \text {-value } & =0.3 \mathrm{~W} / \mathrm{m}^{2} \mathrm{~K} \\
\mathrm{U} \text {-value } & =0.3 \mathrm{~W} / \mathrm{m}^{2} \mathrm{~K}\end{aligned}$ \\
\hline Windows & TERUEL & $\begin{array}{l}\mathrm{U} \text {-value }=5.7 \mathrm{~W} / \mathrm{m}^{2} \mathrm{~K} \text { with shutter } \\
\text { box, } \mathrm{g} \text {-value }=0.85\end{array}$ & $\begin{array}{l}\mathrm{U}=2.70 \mathrm{~W} / \mathrm{m}^{2} \mathrm{~K}, \mathrm{~g} \text {-value }=0.7 \\
\mathrm{~g}, \mathrm{gl}, \text { sh,wi-value }=0.1 \\
\mathrm{U} \text {-value }=1.80 \mathrm{~W} / \mathrm{m}^{2} \mathrm{~K}, \mathrm{~g} \text {-value } \\
=0.7 \\
\mathrm{~g}_{\text {,gl,sh,wi-value }=0.1}\end{array}$ & $\begin{array}{l}\mathrm{U} \text {-value }=2.70 \mathrm{~W} / \mathrm{m}^{2} \mathrm{~K}, \mathrm{~g} \text { - } \\
\text { value }=0.7 \\
\mathrm{~g}_{\text {,gl,sh,wi-value }}=0.1 \\
\mathrm{U} \text {-value }=1.60 \mathrm{~W} / \mathrm{m}^{2} \mathrm{~K}, \mathrm{~g} \text { - } \\
\text { value }=0.7 \\
\mathrm{~g}_{\text {,gl,sh,wi-value }}=0.1\end{array}$ & $\begin{array}{l}\text { U-value }=1.00 \mathrm{~W} / \mathrm{m}^{2} \mathrm{~K}, \mathrm{~g} \text {-value } \\
=0.7 \\
\mathrm{~g}_{\text {,gl,sh,wi-value }=0.1}\end{array}$ \\
\hline $\begin{array}{l}\text { Wall stairs- } \\
\text { dwellings }\end{array}$ & $\begin{array}{l}\text { CADIZ } \\
\text { TERUEL }\end{array}$ & $\begin{array}{l}\mathrm{U} \text {-value }=2.64 \mathrm{~W} / \mathrm{m}^{2} \mathrm{~K}, \mathrm{~m}=101.80 \\
\mathrm{~kg} / \mathrm{m}^{2}\end{array}$ & $\begin{array}{l}\mathrm{U} \text {-value }=2.64 \mathrm{~W} / \mathrm{m}^{2} \mathrm{~K}, \mathrm{~m}= \\
101.80 \mathrm{~kg} / \mathrm{m}^{2}\end{array}$ & $\begin{array}{l}\text { U-value }=0.20 \mathrm{~W} / \mathrm{m}^{2} \mathrm{~K}, \mathrm{~m}= \\
101.80 \mathrm{~kg} / \mathrm{m}^{2}\end{array}$ & $\begin{array}{l}\text { U-value }=0.20 \mathrm{~W} / \mathrm{m}^{2} \mathrm{~K}, \mathrm{~m}= \\
101.80 \mathrm{~kg} / \mathrm{m}^{2}\end{array}$ \\
\hline
\end{tabular}

was assumed to be four.

\subsubsection{Software calculations}

In Portugal there are several available calculation tools to obtain the calculated and maximum values of the building's energy needs, which apply the methodology defined by the regulation. In this paper, the spreadsheet provided by the Platform for Energy Efficiency in Buildings (P3E) of the Institute for Research and Technological Development in Construction, Energy, Environment and Sustainability (Itecons) [41] is used. This spreadsheet is officially accepted for the verification of regulation compliance and in the scope of Building Energy Certification. The calculation is done for each dwelling of a building.

This tool is a quasi-stationary model that consists of a spreadsheet to validate the energy performance of buildings according to methodology described in Ref. [37]. The data required are:

- Envelope main solutions described in Table 3, and its thermal characteristics summarized in Table B1in Appendix B.

- Thermal bridges described in Table B3 in Appendix B.

- Systems described in Section 3.4.1. The energy used for Domestic Hot Water production was calculated according to the reference DHW consumption: 401 per person and per day, heated at $50{ }^{\circ} \mathrm{C}$. The contribution of the solar thermal energy was calculated using the SCE. ER software. This software implements the official methodology of the national thermal regulation [37] regarding renewable energy sources. The energy necessary for lighting and appliances is not considered in this methodology.

- The algorithms to calculate the indicators are detailed in Ref. [70].

To verify the compliance with the Spanish regulation, a simulation tool named HULC (Herramienta Unificada Lider-Calener) was used, which is the official tool in Spain. A new version of this tool was published in January 2020 (version 2.0.2039.1160, June 2020 update) [71], which allows to check the compliance of buildings with the most recent regulation in Spain.

This is a dynamic model tool designed to evaluate the fulfillment with Spanish regulation DB HE. First, the geometry of the building is modeled. Then, the following constructive and technical characteristics are added:

- Envelope main solutions described in Table 4, and its thermal characteristics summarized in Table B2 in Appendix B.

- Thermal bridges described in Table B3 inAppendix B. 
- Systems described in Section 3.4.1. The energy used for Domestic Hot Water production was calculated according to the reference DHW consumption: $28 \mathrm{~L}$ per person and per day, heated at $60{ }^{\circ} \mathrm{C}$ [46]. The contribution of the solar thermal energy in solution $C$ is $60 \%$ of DHW, according to the requirements.

- The energy necessary for lighting and appliances is not considered in this methodology.

\section{Results}

\subsection{Portugal}

Table 5 shows the results of the calculations made for the case of Faro, a warm city in Portugal, and Table 6 shows the results of calculations done for the case of Guarda, a cold city in Portugal. In each table, the information is shown as follows: the first column explains the scenario considered, which is a combination of the envelope solutions (1-4) in Table 3 and systems (A-D). Second and third columns show the results regarding two of the requirements for nZEBs in Portugal and the word "yes" or "no" indicates whether it meets the requirement or not. The fourth column indicates if the case study is finally a nZEB or not, according to all requirements. The last column shows the $\mathrm{CO}_{2}$ emissions of each scenario with the aim of comparing results, because Portugal does not have specific $\mathrm{CO}_{2}$ emissions requirements for nZEB. The emission factors used by the tool are in Table C1, Appendix C.

Additionally, the regulation obliges that $50 \%$ of the primary energy needs are covered by renewable energy sources, and the spreadsheet provides a result of renewable energy for the sum of heating, cooling and DHW.

As can be observed in Tables 5 and $6, \mathrm{~N}_{\mathrm{i}}$ limit is a fixed value, while $\mathrm{N}_{\mathrm{tc}}$ has a variable limit depending on the systems.

For the warm city and the cold city, the nZEB renovation is achieved for cases 3C, 3D, 4C, 4D. Therefore, in Portugal to comply with nZEB renovation requirements it is necessary to both change the systems and retrofit the envelope achieving U-values significantly more restrictive than those to comply with major renovation (between 50 and $74 \%$ lower values, as can be checked in Table 3).

In Portugal, among the renovation scenarios that meet nZEB requirements, the one with the highest value of $\mathrm{CO}_{2}$ emissions is scenario $3 \mathrm{C}$ for the cold city, with 5.12 tons $\mathrm{CO}_{2}$ /year per dwelling (of $84 \mathrm{~m}^{2}$ ), which implies a reduction of $86 \%$ with respect to its original state. The scenario fulfilling the nZEB renovation requirements with the lowest value of $\mathrm{CO}_{2}$ emissions is scenario $4 \mathrm{D}$ for the warm city, with 1.3 tons
$\mathrm{CO}_{2}$ /year per dwelling, which implies a reduction of $89 \%$ with respect to its original state. When looking at all the scenarios fulfilling nZEB renovation requirements we find that the reductions of $\mathrm{CO}_{2}$ emissions achieved in the case of Portugal range between $80 \%$ and $96 \%$, with a mean value of $88 \%$. These reductions are clearly in line with the objectives of the EU to cut domestic greenhouse gas emissions by at least $80 \%$ by 2050 compared to 1990 .

\subsection{Spain}

Table 7 shows the results of the calculations made for the case of Cádiz, a warm city in Spain, and Table 8 shows the results of calculations done for the case of Teruel, a cold city in Spain. In each table, the information is shown as follows: the first column explains the scenario, which is a combination of the envelope solutions (1-4) in Table 4 and systems (A-D). The following four columns show the calculation and requirements to get a nZEB, and the word "yes" or "no" indicates whether it meets the requirements or not. Finally, the last column indicates "yes" or "no", depending on whether all requirements are met simultaneously or not. The last column shows the $\mathrm{CO}_{2}$ emissions of each scenario with the aim of comparing results, because Spain does not have specific $\mathrm{CO}_{2}$ emissions requirements for nZEB. The emission factors used by the tool are in Table C1, Appendix C.

In Spain, the limit of non-renewable energy consumption and total primary energy consumption are a fixed value for each climate zone and independent of the systems, whereas the K-value also depends on the compactness of the building.

For the warm city and the cold city, the nZEB renovation is achieved for cases 2D, 3C, 3D, 4C, 4D. Therefore, in Spain in order to fulfill the nZEB renovation requirements it is necessary to change the systems and to retrofit the envelope achieving U-values that are slightly more restrictive that those required for major renovation (between 0 and $34 \%$ lower values, as can be checked in Table 4), except for the case of electrical systems, in which U-values can be the ones required for major renovation.

In Spain, among the renovation scenarios that meet nZEB renovation requirements, the one with the highest $\mathrm{CO}_{2}$ emissions is scenario $2 \mathrm{D}$ in the cold city, with 5.78 tons $\mathrm{CO}_{2}$ /year per dwelling (of $84 \mathrm{~m}^{2}$ ), which implies a reduction of $91 \%$ with respect to its original state. The scenario fulfilling the nZEB renovation requirements with the lowest value of $\mathrm{CO}_{2}$ emissions is scenario $4 \mathrm{D}$ for the cold city, with 2.0 tons $\mathrm{CO}_{2}$ /year per dwelling, which implies a reduction of $94 \%$ with respect to its original state. When looking at all the scenarios fulfilling nZEB renovation

Table 5

Results for the city of Faro.

\begin{tabular}{|c|c|c|c|c|c|c|c|c|c|}
\hline \multicolumn{2}{|l|}{ Scenario } & \multicolumn{3}{|c|}{$\begin{array}{l}\text { Heating energy annual nominal needs, } \mathrm{N}_{\mathrm{ic}} \\
\left(\mathrm{kWh} / \mathrm{m}^{2} \cdot \text { year }\right)\end{array}$} & \multicolumn{3}{|c|}{$\begin{array}{l}\text { Primary energy annual nominal needs, } \mathrm{N}_{\mathrm{tc}} \\
\left(\mathrm{kWhep} / \mathrm{m}^{2} \cdot \text { year }\right)\end{array}$} & \multirow[t]{2}{*}{ Is it a nZEB? } & \multirow[t]{2}{*}{$\mathrm{CO}_{2}$ emissions (Tons/year) } \\
\hline Envelope solution & System solution & $\begin{array}{l}\text { Calculation: } \\
\mathrm{N}_{\mathrm{ic}}\end{array}$ & $\begin{array}{l}\text { Limit: } \\
75 \% \mathrm{~N}_{\mathrm{i}}\end{array}$ & nZEB? & $\begin{array}{l}\text { Calculation: } \\
\mathrm{N}_{\mathrm{tc}}\end{array}$ & $\begin{array}{l}\text { Limit: } \\
50 \% \mathrm{~N}_{\mathrm{t}}\end{array}$ & nZEB? & & \\
\hline 1 & A & 50.96 & 13.49 & NO & 121.96 & 33.91 & NO & NO & 11.98 \\
\hline 1 & B & 50.96 & 13.49 & NO & 223.29 & 67.62 & NO & NO & 16.22 \\
\hline 1 & $\mathrm{C}$ & 50.96 & 13.49 & NO & 71.15 & 33.91 & NO & NO & 6.90 \\
\hline 1 & $\mathrm{D}$ & 50.96 & 13.49 & NO & 46.28 & 28.03 & NO & NO & 3.36 \\
\hline 2 & A & 20.42 & 12.92 & NO & 81.99 & 33.48 & NO & NO & 8.84 \\
\hline 2 & B & 20.42 & 12.92 & NO & 146.93 & 66.67 & NO & NO & 10.68 \\
\hline 2 & $\mathrm{C}$ & 20.42 & 12.92 & NO & 41.39 & 33.48 & NO & NO & 3.76 \\
\hline 2 & $\mathrm{D}$ & 20.42 & 12.92 & NO & 30.08 & 27.71 & NO & NO & 2.18 \\
\hline 3 & A & 5.46 & 12.92 & YES & 64.71 & 33.48 & NO & NO & 6.64 \\
\hline 3 & B & 5.46 & 12.92 & YES & 111.81 & 66.67 & NO & NO & 8.10 \\
\hline 3 & $\mathrm{C}$ & 5.46 & 12.92 & YES & 29.06 & 33.48 & YES & YES & 2.40 \\
\hline 3 & $\mathrm{D}$ & 5.46 & 12.92 & YES & 24.41 & 27.71 & YES & YES & 1.76 \\
\hline 4 & $\mathrm{~A}$ & 1.37 & 12.92 & YES & 55.23 & 33.48 & NO & NO & 5.68 \\
\hline 4 & B & 1.37 & 12.92 & YES & 97.45 & 66.67 & NO & NO & 7.08 \\
\hline 4 & C & 1.37 & 12.92 & YES & 20.94 & 33.48 & YES & YES & 1.72 \\
\hline 4 & $\mathrm{D}$ & 1.37 & 12.92 & YES & 18.11 & 27.71 & YES & YES & 1.30 \\
\hline
\end{tabular}


Table 6

Results for the city of Guarda.

\begin{tabular}{|c|c|c|c|c|c|c|c|c|c|}
\hline \multicolumn{2}{|l|}{ Scenario } & \multicolumn{3}{|c|}{$\begin{array}{l}\text { Heating energy annual nominal needs, } \mathrm{N}_{\mathrm{ic}} \\
\left(\mathrm{kWh} / \mathrm{m}^{2} \text {.year }\right)\end{array}$} & \multicolumn{3}{|c|}{$\begin{array}{l}\text { Primary energy annual nominal needs } \mathrm{N}_{\mathrm{tc}} \\
\text { (kWhep } / \mathrm{m}^{2} \cdot \text { year) }\end{array}$} & \multirow[t]{2}{*}{ Is it a nZEB? } & \multirow[t]{2}{*}{$\mathrm{CO}_{2}$ emissions (Tons/year) } \\
\hline Envelope solution & System solution & $\begin{array}{l}\text { Calculation: } \\
\mathrm{N}_{\mathrm{ic}}\end{array}$ & $\begin{array}{l}\text { Limit: } \\
75 \% \mathrm{~N}_{\mathrm{i}}\end{array}$ & nZEB? & $\begin{array}{l}\text { Calculation: } \\
\mathrm{N}_{\mathrm{tc}}\end{array}$ & $\begin{array}{l}\text { Limit: } \\
50 \% \mathrm{~N}_{\mathrm{t}}\end{array}$ & nZEB? & & \\
\hline 1 & A & 231.71 & 51.56 & NO & 350.35 & 57.37 & NO & NO & 35.60 \\
\hline 1 & B & 231.71 & 51.56 & NO & 627.1 & 125.68 & NO & NO & 48.38 \\
\hline 1 & $\mathrm{C}$ & 231.71 & 51.56 & NO & 234.58 & 57.37 & NO & NO & 23.82 \\
\hline 1 & $\mathrm{D}$ & 231.71 & 51.56 & NO & 134.09 & 44.13 & NO & NO & 9.74 \\
\hline 2 & A & 109.78 & 49.86 & NO & 189.13 & 56.11 & NO & NO & 21.96 \\
\hline 2 & B & 109.78 & 49.86 & NO & 360.62 & 123.21 & NO & NO & 26.16 \\
\hline 2 & $\mathrm{C}$ & 109.78 & 49.86 & NO & 118.60 & 56.11 & NO & NO & 11.96 \\
\hline 2 & $\mathrm{D}$ & 109.78 & 49.86 & NO & 67.56 & 43.19 & NO & NO & 4.9 \\
\hline 3 & A & 39.47 & 49.86 & YES & 99.66 & 56.11 & NO & NO & 11.54 \\
\hline 3 & B & 39.47 & 49.86 & YES & 187.29 & 123.21 & NO & NO & 13.60 \\
\hline 3 & $\mathrm{C}$ & 39.47 & 49.86 & YES & 52.66 & 56.11 & YES & YES & 5.12 \\
\hline 3 & $\mathrm{D}$ & 39.47 & 49.86 & YES & 32.92 & 43.19 & YES & YES & 2.40 \\
\hline 4 & A & 18.86 & 49.84 & YES & 71.99 & 56.11 & NO & NO & 7.12 \\
\hline 4 & B & 18.86 & 49.84 & YES & 135.54 & 123.21 & NO & NO & 9.82 \\
\hline 4 & $\mathrm{C}$ & 18.86 & 49.84 & YES & 31.88 & 56.11 & YES & YES & 3.02 \\
\hline 4 & $\mathrm{D}$ & 18.86 & 49.84 & YES & 21.27 & 43.19 & YES & YES & 1.56 \\
\hline
\end{tabular}

requirements we find that the reductions of $\mathrm{CO}_{2}$ emissions achieved in the case of Spain range between $71 \%$ and $94 \%$, with a mean value of $81 \%$. These reductions are also in line with the objectives of the EU to cut domestic greenhouse gas emissions by at least $80 \%$ by 2050 compared to 1990 .

\section{Discussion}

This paper studies the nZEB renovation definition in the most recent regulations of Portugal and Spain, analysing in detail the thermal requirements for the envelope applied to a specific typology. The typology chosen here is the typical multifamily building of Portugal and Spain built between 1961 and 1980 .

After studying the construction requirements established in Portugal and Spain for a nZEB renovation, and checking whether an existing building refurbished with different combinations of improvements of the envelope and active systems in two cities of Portugal and two cities of Spain -a cold and a warm one-, complies or not with these requirements, the research questions posed previously are answered in the light of the results.

The Portuguese regulation does not have a specific definition for nZEB renovation. The same requirements as for new nZEBs must be met if you wish to transform an existing building into a nZEB. In the case of Spain there is a specific nZEB renovation definition but it is not mandatory when a building is renovated.

\subsection{Research questions}

1 Are the nZEB requirements for the thermal characteristics of the refurbished envelope equivalent in Portugal and Spain for colder and warmer cities? If not, what implications do differences have?

The nZEB requirements for the envelope differ mainly in the way the energy demand and use is limited. With respect to the energy demand:

- In Spain to limit the energy demand of buildings, the K-value is used, which is a static value that depends exclusively on the U-values of the envelope solution and the thermal bridges. Additionally, the indicator total primary energy consumption is defined, that limits the energy use to heating, cooling and DHW, using a method that considers not only the U-values and thermal bridges, but also the thermal inertia, the internal gains, the ventilation, etc.
- In Portugal, the annual nominal final energy need for space heating is used as well as the nominal value of estimated primary energy needs which takes into account the energy needs for space heating/cooling and for DHW. Both indicators of the Portuguese regulation rely on a method that considers not only the U-values and thermal bridges, but also the thermal inertia, the internal gains, the ventilation, etc.

Furthermore, Portuguese and Spanish regulations define also other specific requirements (maximum values) for certain parameters like Uvalues and Solar Factors.

On the other hand, in both Portugal and Spain it is essential to shade the windows in summer, for all orientations and climate zones, even in the north façade although to a lower extent. This is a positive measure in both countries.

Regarding the method of estimation of energy use, in Spain, a dynamic model is used, whereas in Portugal the quasi-stationary model previously described is used. The results in Spain can be considered more precise, depending however on the precision of data, but both of them have scientific validity.

Regarding the limitation of the energy use, in Spain, a fixed limit is established for all types of active systems, whereas in Portugal the limit is a percentage of the value of the reference building. So, in Portugal, the limit of the primary energy needs for a building to be a nZEB depends on the chosen type of system, specifically on a reference value of its efficiency and on the conversion factors for its source of energy. It should be explored if a limit for the primary energy needs should be independent of the systems, with a fixed value as in the Spanish regulation.

With respect to the limitation of the energy use, it must be added that whereas in Portugal at least $50 \%$ of the primary energy must come from renewable sources, in Spain a maximum value of non-renewable primary energy use is set. This way of regulating the use of renewable energy in Spain can cause that the percentage of energy from renewable sources may be below $50 \%$ when the total primary energy consumption is below the established limit (Table A1, Appendix A).

Even if the limits for all these parameters are different in Portugal and Spain (Table A1, Appendix A), when applying them to the renovation of a typical multi-family building of the period 1961-1980, in comparable warm and cold cities of both countries, we find that there are slight differences in terms of $\mathrm{CO}_{2}$ emissions reductions between the two countries. In the case of Portugal the nZEB renovations show reductions with respect to the original building with a mean value seven units above the mean reduction achieved with the Spanish regulation (reduction of $88 \%$ of $\mathrm{CO}_{2}$ emissions in Portugal vs. $81 \%$ in Spain). In any 

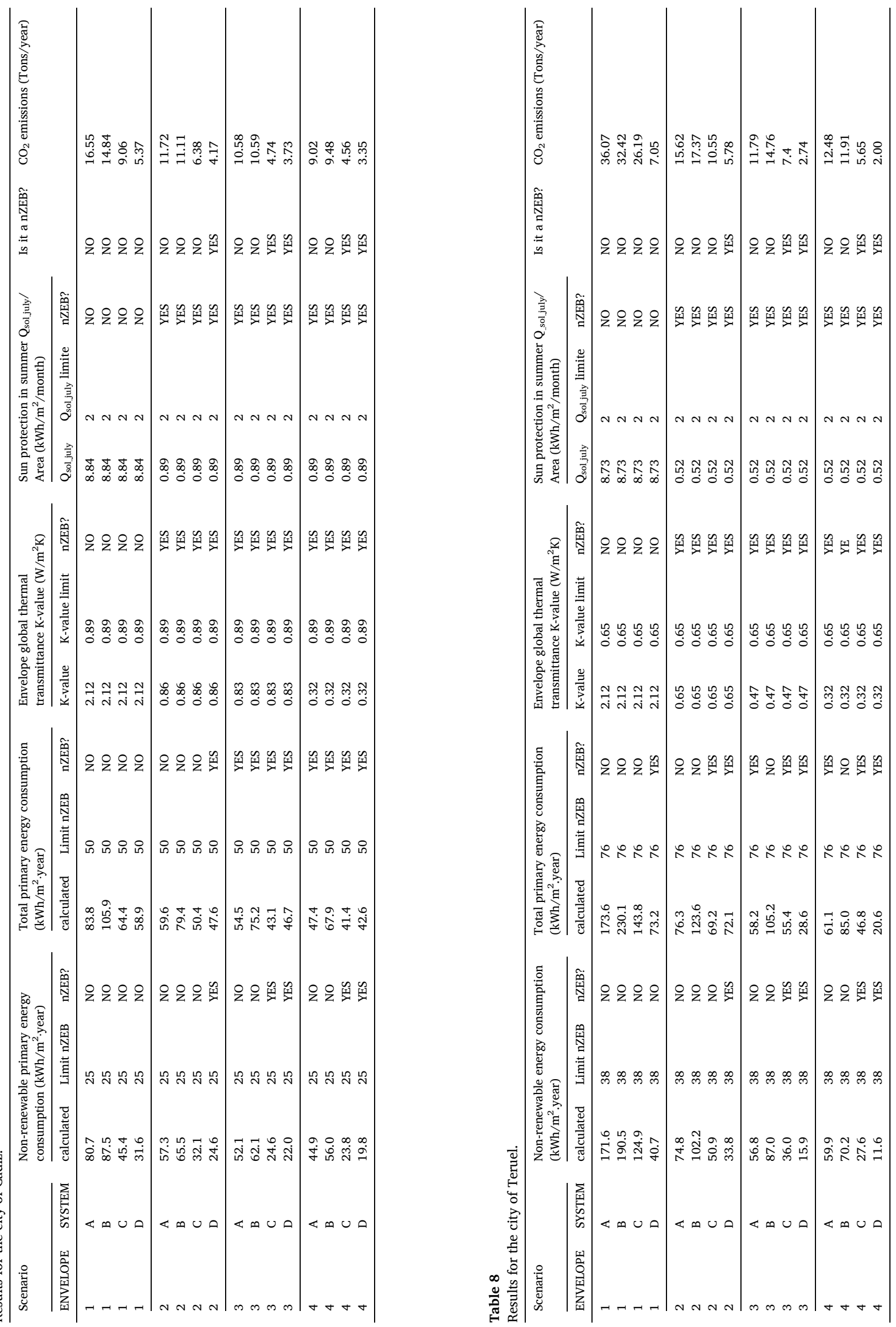
case, both of them can be useful to achieve the objectives of the EU to cut domestic greenhouse gas emissions by at least $80 \%$ by 2050 compared to 1990. However, these standards are not compulsory at this moment in none of the two countries as previously mentioned.

2 What thermal characteristics of the envelope allow to comply with the nZEB renovation requirements? Is it necessary to additionally improve the active systems to achieve nZEB requirements or is the improvement of the envelope enough?

Both in Portugal and Spain, it is possible to fulfill nZEB renovation requirements using low U-values (solution 4 of Tables 3 and 4), and higher U-values suggested or required in the regulations for new buildings (solution 3 in Tables 3 and 4 ) if the systems are changed. Additionally, in Spain, it is possible to achieve the nZEB renovation standard for this building typology using the maximum U-values required for major renovations (solution 2 in Table 4) when the systems are changed to electrical systems. This is considered a positive measure towards the decarbonization of the building stock in Spain because the major renovations that are performed using this regulation, which is compulsory when more of the $25 \%$ of the envelope is refurbished, in this type of building will allow to achieve the nZEB standard or be close to it.

U-value requirements to major renovations in Portugal are less demanding than Spanish ones for the cities with similar characteristics (Table 3), and in Portugal the requirements to major renovations are insufficient to achieve nZEBs (scenarios 2A, 2B, 2C, 2D).

3 What are the specific conclusions of these nZEB renovation requirements for this building typology?

The simulations show that in the renovation of this building typology, characterized by shaded windows, high internal thermal inertia and cross-ventilation, the lower the U-values of the envelope, the best the energy performance of the refurbished buildings. Even if low U-values imply an overheating in summer, the positive influence of shading, high internal thermal intertie, and cross-ventilation makes the emissions associated to overheating be much lower than the saved emissions associated to heating thanks to low U-values of the envelope. This has also been observed in other studies of renovation of residential buildings in Spain within the same period [18].

\section{Conclusions}

In this work, the Portuguese and Spanish nZEB renovation regulations for the thermal properties of the envelope is analysed in detail for the multi-family building of 1961-1980 tipology. Using the national tools of these countries, different combinations of envelope and systems retrofitting were simulated, in two cities of each country: a warm city and a cold city. In total 224 calculations were performed: 32 for Spain and 192 for Portugal. The difference in the number of simulations is due to the fact that in Spain the calculation is per building, and in Portugal per dwelling. Next, we draw the main conclusions for policy makers and researchers dealing with the definition of the nZEB renovation concept.

The nZEB renovation requirements models in both countries differ mainly in the way the energy demand and the energy use are limited. Anyhow, the $\mathrm{CO}_{2}$ emissions reduction results show that the nZEB standards applied to the renovation of typical multi-family buildings of 1961-1980 in both countries will significantly contribute to the decarbonization of the building stock in this type of building typology, with reductions of $80-96 \%$ of $\mathrm{CO}_{2}$ emissions for Portugal and $71-94 \%$ for
Spain, if they are applied.

To limit the energy use in Spain, a fixed limit is established for all types of active systems, whereas in Portugal the limit is a percentage of the value of the reference building depends on the chosen type of system. It should be explored if in Portugal a limit for the primary energy needs should be independent of the systems, with a fixed value as in the Spanish regulation.

The results show that in both countries it is necessary to change the active systems to achieve nZEB requirements and retrofit the envelope achieving U-values more restrictive that the required for major renovations. However, in Spain it is possible to achieve a nZEB renovation when maximum U-values for major renovations are used and the systems are changed to electrical ones. These restrictive U-values in Spain for major renovation are seen here as a good practice towards the decarbonization of the residential sector because they ensure that we already approach to the decarbonization of the residential sector. Portugal should encourage the adoption of more restrictive measures for major renovations.

In Portugal at least $50 \%$ of the primary energy must come from renewable sources, but in Spain a maximum value of non-renewable primary energy use is set. This way of regulating the use of renewable energy in Spain can cause that the percentage of energy from renewable sources may be below $50 \%$ when the total primary energy consumption is below the established limit. Spain should guarantee a $50 \%$ of energy from local/in situ renewable sources and also encourage nZEB renovations.

In these two countries the nZEB regulation requires to shade the windows to limit the energy performance for the warm season. However, no indicator is used to specifically limit the cooling energy performance. It is implicit in the total primary energy use indicator, but together with other energy consumptions from heating and DHW. It should be explored if this is the best in the event that climate change makes cooling demands more restricting.

\section{CRediT authorship contribution statement}

Marta Monzón-Chavarrías: Conceptualization, Methodology, Software, Investigation, Data curation, Writing - original draft, Project administration, Funding acquisition. Belinda López-Mesa: Conceptualization, Methodology, Supervision, Writing - review \& editing, Funding acquisition. Jaime Resende: Methodology, Software, Investigation, Writing - review \& editing. Helena Corvacho: Conceptualization, Methodology, Resources, Supervision, Writing - review \& editing, Funding acquisition.

\section{Declaration of competing interest}

The authors declare that they have no known competing financial interests or personal relationships that could have appeared to influence the work reported in this paper.

\section{Acknowledgements}

In Spain, this work was funded by University of Zaragoza, Bank foundation Ibercaja, and foundation CAI [grant number IT4/19], and by FEDER 2014-2020 [project "Construyendo Europa desde Aragón", research group T37_17R "Grupo de Investigación en Arquitectura"]. In Portugal, this work was financially supported by UID/ECI/04708/2019CONSTRUCT - Instituto de I\&D em Estruturas e Construções, funded by national funds through the FCT/MCTES (PIDDAC). 


\section{Appendix A}

Table A1

Comparison of main requirements for major renovation and nZEB renovation in Portugal and Spain

\begin{tabular}{|c|c|c|c|c|}
\hline \multirow{2}{*}{$\begin{array}{l}\text { Currently requirements for residential } \\
\text { buildings }\end{array}$} & \multicolumn{2}{|l|}{ Portugal } & \multicolumn{2}{|l|}{ Spain } \\
\hline & Major renovation & $\begin{array}{l}\text { nZEB renovation (requirements not specifically } \\
\text { defined for renovation and not mandatory) }\end{array}$ & $\begin{array}{l}\text { Major } \\
\text { renovation }\end{array}$ & $\begin{array}{l}\text { nZEB renovation } \\
\text { (requirements not } \\
\text { mandatory) }\end{array}$ \\
\hline Compulsory? & Yes & No & Yes & No \\
\hline Specific definition? & Yes & No & Yes & Yes \\
\hline \multirow{8}{*}{$\begin{array}{l}\text { Non-renewable primary energy use } \\
\text { limit }\end{array}$} & - & $<50 \%$ total primary energy use & \multicolumn{2}{|c|}{ Maximum values $\left(\mathrm{kW} \cdot \mathrm{h} / \mathrm{m}^{2} \cdot\right.$ year $)$} \\
\hline & & & 40 (zone $\alpha)$ & 20 (zone $\alpha)$ \\
\hline & & & 50 (zone A) & 25 (zone A) \\
\hline & & & 55 (zone B) & 28 (zone B) \\
\hline & & & 65 (zone C) & 32 (zone C) \\
\hline & & & 70 (zone D) & 38 (zone D) \\
\hline & & & 80 (zone E) & 43 (zone E) \\
\hline & & & \multicolumn{2}{|c|}{$<40 \%$ of the energy demand for DHW } \\
\hline \multirow[t]{7}{*}{ Total primary energy use limits } & \multirow{7}{*}{$\begin{array}{l}\mathrm{N}_{\mathrm{tc}} / \mathrm{N}_{\mathrm{t}} \leq 1.5 \text { or } 2.0 \text {, depending on } \\
\text { the extension of the renovation }\end{array}$} & \multirow{7}{*}{$\leq 50 \%$ of $\mathrm{N}_{\mathrm{t}}$ (which varies for each building) } & \multicolumn{2}{|c|}{ Maximum values $\left(\mathrm{kW} \cdot \mathrm{h} / \mathrm{m}^{2} \cdot\right.$ year $)$} \\
\hline & & & 55 (zone $\alpha)$ & 40 (zone $\alpha$ ) \\
\hline & & & 75 (zone A) & 50 (zone A) \\
\hline & & & 80 (zone B) & 56 (zone B) \\
\hline & & & 90 (zone C) & 64 (zone C) \\
\hline & & & 105 (zone D) & 76 (zone D) \\
\hline & & & 115 (zone E) & 86 (zone E) \\
\hline $\begin{array}{l}\text { Total final energy use for heating limit } \\
\left(\mathrm{kW} \cdot \mathrm{h} / \mathrm{m}^{2} \cdot \text { year }\right)\end{array}$ & - & $\leq 75 \% \mathrm{~N}_{\mathrm{i}}$ (which varies for each building) & - & - \\
\hline Cooling requirements & Shading the windows & Shading the windows & Shading the $\mathrm{w}$ & lows \\
\hline \multirow{14}{*}{$\begin{array}{l}\text { U-values of the } \\
\text { envelope }(\mathrm{kW} \cdot \mathrm{h} / \\
\left.\mathrm{m}^{2} \cdot \text { year }\right)\end{array}$} & Maximum allowable values $\left(\mathrm{W} / \mathrm{m}^{2} \mathrm{~K}\right)$ & & Maximum val & $\left(\mathrm{W} / \mathrm{m}^{2} \mathrm{~K}\right)$ \\
\hline & 1.70 (I1) & Not defined for a nZEB renovation & $0.80($ zone $\alpha)$ & $0.80($ zone $\alpha)$ \\
\hline & 1.50 (I2) & & 0.70 (zone $\mathrm{A})$ & 0.70 (zone A) \\
\hline & 1.40 (I3) & & 0.56 (zone B) & 0.56 (zone B) \\
\hline & & & 0.49 (zone C) & 0.49 (zone C) \\
\hline & & & 0.41 (zone D) & 0.41 (zone D) \\
\hline & & & 0.37 (zone E) & 0.37 (zone E) \\
\hline & & & Suggested valu & $\left(\mathrm{W} / \mathrm{m}^{2} \mathrm{~K}\right)$ \\
\hline & & & 0.56 (zone $\alpha)$ & 0.56 (zone $\alpha$ ) \\
\hline & & & 0.50 (zone A) & 0.50 (zone $\mathrm{A}$ ) \\
\hline & & & 0.38 (zone $\mathrm{B})$ & 0.38 (zone B) \\
\hline & & & 0.29 (zone C) & 0.29 (zone C) \\
\hline & & & 0.27 (zone D) & 0.27 (zone D) \\
\hline & & & 0.23 (zone $\mathrm{E})$ & 0.23 (zone E) \\
\hline Roofs & Maximum allowable values $\left(\mathrm{W} / \mathrm{m}^{2} \mathrm{~K}\right)$ & & Maximum val & $\left(\mathrm{W} / \mathrm{m}^{2} \mathrm{~K}\right)$ \\
\hline & 0.8 (I1) & Not defined for a nZEB renovation & 0.55 (zone $\alpha)$ & 0.55 (zone $\alpha)$ \\
\hline & 0.7 (I2) & & 0.50 (zone A) & 0.50 (zone A) \\
\hline & 0.6 (I3) & & 0.44 (zone B) & 0.44 (zone B) \\
\hline & & & 0.40 (zone $\mathrm{C}$ ) & 0.40 (zone C) \\
\hline & & & 0.35 (zone $\mathrm{D})$ & 0.35 (zone D) \\
\hline & & & 0.33 (zone E) & 0.33 (zone E) \\
\hline & & & Suggested valı & $\left(\mathrm{W} / \mathrm{m}^{2} \mathrm{~K}\right)$ \\
\hline & & & $0.50($ zone $\alpha)$ & $0.50($ zone $\alpha)$ \\
\hline & & & 0.44 (zone A) & 0.44 (zone A) \\
\hline & & & 0.33 (zone $\mathrm{B}$ ) & 0.33 (zone B) \\
\hline & & & 0.23 (zone C) & 0.23 (zone $\mathrm{C}$ ) \\
\hline & & & $0.22($ zone $\mathrm{D})$ & 0.22 (zone D) \\
\hline & & & 0.19 (zone E) & 0.19 (zone E) \\
\hline Ground & - & - & Maximum val & $\left(\mathrm{W} / \mathrm{m}^{2} \mathrm{~K}\right)$ \\
\hline floor & & & $0.90($ zone $\alpha)$ & $0.90($ zone $\alpha)$ \\
\hline & & & 0.80 (zone $\mathrm{A})$ & 0.80 (zone A) \\
\hline & & & 0.75 (zone B) & 0.75 (zone B) \\
\hline & & & 0.70 (zone $\mathrm{C}$ ) & 0.70 (zone $\mathrm{C}$ ) \\
\hline & & & 0.65 (zone D) & 0.65 (zone D) \\
\hline & & & 0.59 (zone E) & 0.59 (zone E) \\
\hline & & & Suggested valu & $\left(\mathrm{W} / \mathrm{m}^{2} \mathrm{~K}\right)$ \\
\hline & & & $0.80($ zone $\alpha)$ & $0.80($ zone $\alpha)$ \\
\hline & & & 0.80 (zone $\mathrm{A})$ & 0.80 (zone $\mathrm{A})$ \\
\hline & & & 0.69 (zone B) & 0.69 (zone B) \\
\hline & & & 0.48 (zone $\mathrm{C}$ ) & 0.48 (zone $\mathrm{C}$ ) \\
\hline & & & 0.48 (zone $\mathrm{D})$ & 0.48 (zone D) \\
\hline & & & 0.48 (zone E) & 0.48 (zone E) \\
\hline Windows & Maximum values $\left(\mathrm{W} / \mathrm{m}^{2} \mathrm{~K}\right)$ & & Maximum val & $\left(\mathrm{W} / \mathrm{m}^{2} \mathrm{~K}\right)$ \\
\hline & 4.5 (I1) & Not defined for a nZEB renovation & $3.2($ zone $\alpha)$ & $3.2($ zone $\alpha)$ \\
\hline & 4.0 (I2) & & 2.7 (zone A) & 2.7 (zone A) \\
\hline & 4.9 (I3) & & 2.3 (zone B) & 2.3 (zone B) \\
\hline & & & 2.1 (zone C) & 2.1 (zone C) \\
\hline
\end{tabular}


Table A1 (continued)

\begin{tabular}{|c|c|c|c|c|}
\hline \multirow{2}{*}{$\begin{array}{l}\text { Currently requirements for residential } \\
\text { buildings }\end{array}$} & \multicolumn{2}{|l|}{ Portugal } & \multicolumn{2}{|l|}{ Spain } \\
\hline & Major renovation & $\begin{array}{l}\text { nZEB renovation (requirements not specifically } \\
\text { defined for renovation and not mandatory) }\end{array}$ & $\begin{array}{l}\text { Major } \\
\text { renovation }\end{array}$ & $\begin{array}{l}\text { nZEB renovation } \\
\text { (requirements not } \\
\text { mandatory) }\end{array}$ \\
\hline & & & 1.8 (zone D) & 1.8 (zone D) \\
\hline & & & 1.8 (zone E) & 1.8 (zone E) \\
\hline & & & \multicolumn{2}{|c|}{ Suggested values $\left(\mathrm{W} / \mathrm{m}^{2} \mathrm{~K}\right)$} \\
\hline & & & $2.7($ zone $\alpha)$ & $2.7($ zone $\alpha)$ \\
\hline & & & 2.7 (zone A) & 2.7 (zone A) \\
\hline & & & 2.0 (zone B) & 2.0 (zone B) \\
\hline & & & 2.0 (zone C) & 2.0 (zone C) \\
\hline & & & 1.6 (zone D) & 1.6 (zone D) \\
\hline & & & 1.5 (zone E) & 1.5 (zone E) \\
\hline \multirow[t]{7}{*}{$\begin{array}{l}\text { Thermal } \\
\text { bridges }\end{array}$} & - & - & $\begin{array}{l}\text { Maximum K- } \\
\text { value* }\end{array}$ & Maximum K-value* \\
\hline & & & $1.0($ zone $\alpha)$ & 0.67 (zone $\alpha)$ \\
\hline & & & 0.87 (zone A) & 0.60 (zone A) \\
\hline & & & 0.83 (zone B) & 0.58 (zone B) \\
\hline & & & 0.73 (zone $\mathrm{C}$ ) & 0.53 (zone C) \\
\hline & & & 0.63 (zone D) & 0.48 (zone D) \\
\hline & & & 0.54 (zone E) & 0.43 (zone E) \\
\hline
\end{tabular}

*For a building with a compacity of $1 . \mathrm{N}_{\mathrm{ic}}$ : annual nominal final energy need for heating; $\mathrm{N}_{\mathrm{i}}$ : maximum value of annual nominal final energy need for heating; $\mathrm{N}_{\mathrm{tc}}$ : nominal energy needs of primary energy; $\mathrm{N}_{\mathrm{t}}$ : maximum value of nominal energy needs of primary energy. In both countries, the nZEB renovation must comply with major renovation requirements. I1, I2, I3: Portuguese winter climate zones. Zone $\alpha$, A, B, C, D, E: Spanish winter climate zones.

\section{Appendix B. Considered input data in calculations}

Table B1

Data used in Portuguese simulation

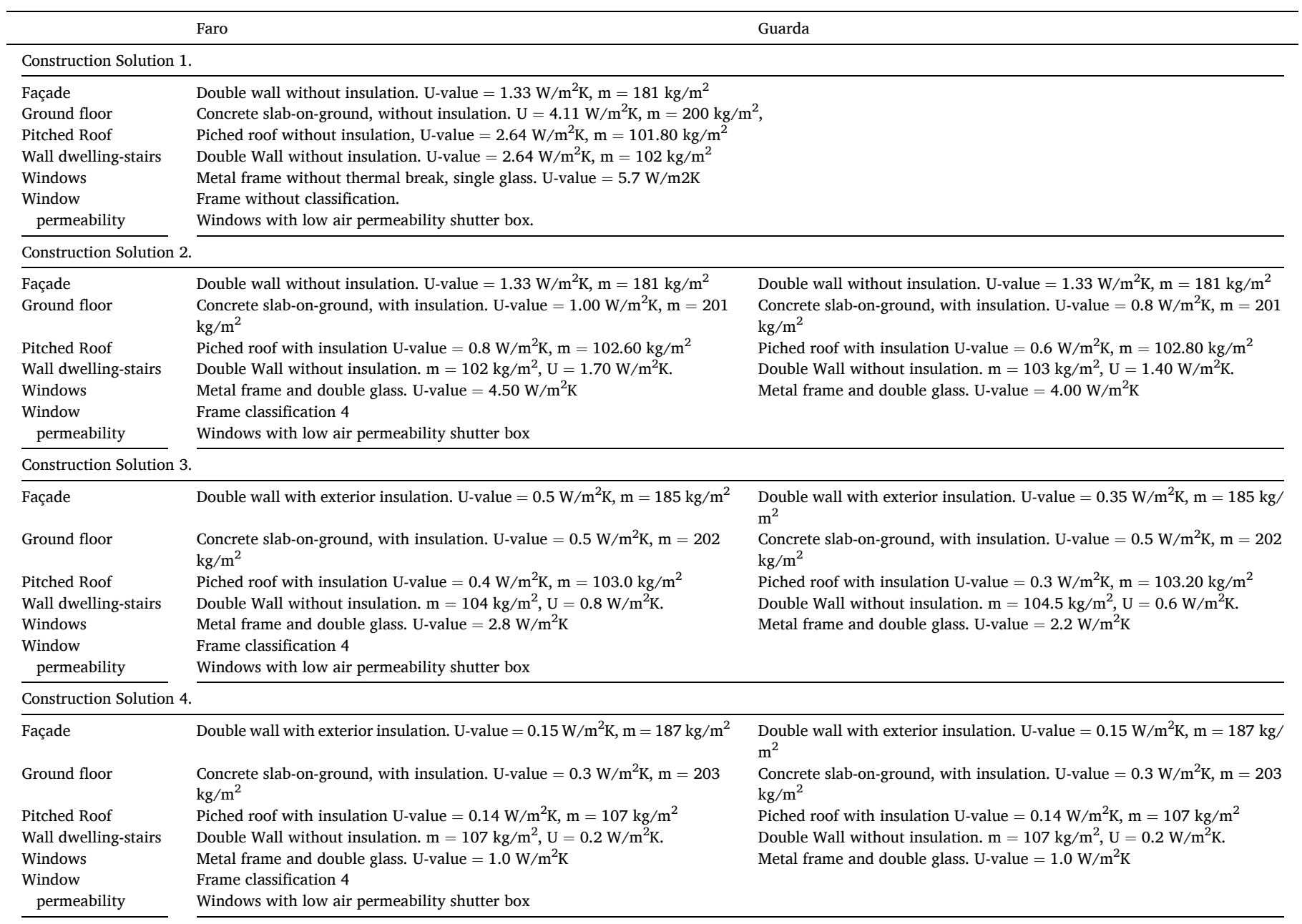


Table B1 (continued)

\begin{tabular}{|c|c|}
\hline & Guarda \\
\hline \multicolumn{2}{|c|}{ Other parameters (solutions 1-4) } \\
\hline Ventilation & Natural admission by windows. $34.65 \mathrm{l} / \mathrm{s}$ per dwelling (according to Despacho 15,793- K [72]) \\
\hline Permeability $\mathrm{n}_{50}$ & By default \\
\hline DHW & 401 per person and per day, heated at $50^{\circ} \mathrm{C}$ \\
\hline
\end{tabular}

\section{Table B2}

Data used in the simulations for the Spanish cities.

\begin{tabular}{|c|c|c|}
\hline & Cádiz & Teruel \\
\hline \multicolumn{3}{|c|}{ Construction Solution 1.} \\
\hline $\begin{array}{l}\text { Façade } \\
\text { Ground floor } \\
\text { Pitched Roof } \\
\text { Windows } \\
\text { Windows } \\
\text { permeability }\end{array}$ & \multicolumn{2}{|l|}{$\begin{array}{l}2.5 \mathrm{~cm} \text { mortar cement coating }+11 \mathrm{~cm} \text { hollow brick }+1 \\
10 \mathrm{~cm} \text { concrete slab-on-ground }+2 \mathrm{~cm} \text { stone paving } \\
\text { Pitched roof with woden board and ceramic tiles. } \\
\text { Metal frame without termal break, simple glass } 3 \mathrm{~mm} \text {. } \\
\text { air permeability of } 50 \mathrm{~m}^{3} / \mathrm{h}_{-} \mathrm{m}^{2}\end{array}$} \\
\hline \multicolumn{3}{|c|}{ Construction Solution 2.} \\
\hline Façade & $\begin{array}{l}2.5 \mathrm{~cm} \text { mortar cement coating }+2 \mathrm{~cm} \text { EPS }(\lambda=0.029 \mathrm{~W} / \mathrm{mK})+11 \mathrm{~cm} \text { hollow } \\
\text { brick }+1.5 \mathrm{~cm} \text { mortar cement coating }+2 \mathrm{~cm} \text { nonventilated air space }+4 \mathrm{~cm} \\
\text { hollow brick }+1.5 \mathrm{~cm} \text { plastering. }\end{array}$ & $\begin{array}{l}2.5 \mathrm{~cm} \text { mortar cement coating }+5 \mathrm{~cm} \text { EPS }(\lambda=0.029 \mathrm{~W} / \mathrm{mK})+11 \mathrm{~cm} \text { hollow } \\
\text { brick }+1.5 \mathrm{~cm} \text { mortar cement coating }+2 \mathrm{~cm} \text { nonventilated air space }+4 \mathrm{~cm} \\
\text { hollow brick }+1.5 \mathrm{~cm} \text { plastering. }\end{array}$ \\
\hline Ground floor & $\begin{array}{l}10 \mathrm{~cm} \text { concrete slab-on-ground }+3.5 \mathrm{~cm} \text { XPS }(\lambda=0.034 \mathrm{~W} / \mathrm{mK})+\mathrm{C} 2 \mathrm{~cm} \text { stone } \\
\text { paving. }\end{array}$ & $\begin{array}{l}10 \mathrm{~cm} \text { concrete slab-on-ground }+4 \mathrm{~cm} \text { XPS }(\lambda=0.034 \mathrm{~W} / \mathrm{mK})+\mathrm{C} 2 \mathrm{~cm} \text { stone } \\
\text { paving. }\end{array}$ \\
\hline Pitched Roof & $\begin{array}{l}\text { Pitched roof with woden board and ceramic tiles and } 3.5 \mathrm{~cm} \text { XPS }(\lambda=0.034 \mathrm{~W} / \\
\mathrm{mK}) \text {. }\end{array}$ & $\begin{array}{l}\text { Pitched roof with woden board and ceramic tiles and } 8 \mathrm{~cm} \text { XPS }(\lambda=0.034 \mathrm{~W} / \\
\mathrm{mK}) \text {. }\end{array}$ \\
\hline $\begin{array}{l}\text { Windows } \\
\text { Windows } \\
\text { permeability }\end{array}$ & $\begin{array}{l}\text { Metal frame with termal bridge and double glass. } \\
\text { air permeability of } 27 \mathrm{~m}^{3} / \mathrm{h}_{-} \mathrm{m}^{2}\end{array}$ & $\begin{array}{l}\text { Metal frame with termal bridge and double glass. } \\
\text { air permeability of } 3 \mathrm{~m}^{3} / \mathrm{h}_{-} \mathrm{m}^{2}\end{array}$ \\
\hline \multicolumn{3}{|c|}{ Construction Solution 3.} \\
\hline Façade & $\begin{array}{l}2.5 \mathrm{~cm} \text { mortar cement coating }+3.5 \mathrm{~cm} \text { EPS }(\lambda=0.029 \mathrm{~W} / \mathrm{mK})+11 \mathrm{~cm} \text { hollow } \\
\text { brick }+1.5 \mathrm{~cm} \text { mortar cement coating }+2 \mathrm{~cm} \text { nonventilated air space }+4 \mathrm{~cm} \\
\text { hollow brick }+1.5 \mathrm{~cm} \text { plastering. }\end{array}$ & $\begin{array}{l}2.5 \mathrm{~cm} \text { mortar cement coating }+8.5 \mathrm{~cm} \text { EPS }(\lambda=0.029 \mathrm{~W} / \mathrm{mK})+11 \mathrm{~cm} \text { hollow } \\
\text { brick }+1.5 \mathrm{~cm} \text { mortar cement coating }+2 \mathrm{~cm} \text { nonventilated air space }+4 \mathrm{~cm} \\
\text { hollow brick }+1.5 \mathrm{~cm} \text { plastering. }\end{array}$ \\
\hline Ground floor & $\begin{array}{l}10 \mathrm{~cm} \text { concrete slab-on-ground }+2.6 \mathrm{~cm} \text { XPS }(\lambda=0.034 \mathrm{~W} / \mathrm{mK})+\mathrm{C} 2 \mathrm{~cm} \text { stone } \\
\text { paving. }\end{array}$ & $\begin{array}{l}10 \mathrm{~cm} \text { concrete slab-on-ground }+6 \mathrm{~cm} \text { XPS }(\lambda=0.034 \mathrm{~W} / \mathrm{mK})+\mathrm{C} 2 \mathrm{~cm} \text { stone } \\
\text { paving. }\end{array}$ \\
\hline Pitched Roof & $\begin{array}{l}\text { Pitched roof with woden board and ceramic tiles and } 5.5 \mathrm{~cm} \text { XPS }(\lambda=0.034 \mathrm{~W} / \\
\mathrm{mK}) \text {. }\end{array}$ & $\begin{array}{l}\text { Pitched roof with woden board and ceramic tiles and } 13 \mathrm{~cm} \text { XPS }(\lambda=0.034 \mathrm{~W} / \\
\mathrm{mK}) \text {. }\end{array}$ \\
\hline $\begin{array}{l}\text { Windows } \\
\text { Windows } \\
\text { permeability }\end{array}$ & $\begin{array}{l}\text { Metal frame with termal bridge and double glass. } \\
\text { air permeability of } 9 \mathrm{~m}^{3} / \mathrm{h}_{-} \mathrm{m}^{2}\end{array}$ & $\begin{array}{l}\text { Metal frame with termal bridge and double glass. } \\
\text { air permeability of } 3 \mathrm{~m}^{3} / \mathrm{h}_{-} \mathrm{m}^{2}\end{array}$ \\
\hline \multicolumn{3}{|c|}{ Construction Solution 4.} \\
\hline Façade & \multicolumn{2}{|c|}{$\begin{array}{l}2.5 \mathrm{~cm} \text { mortar cement coating }+17 \mathrm{~cm} \text { EPS }(\lambda=0.029 \mathrm{~W} / \mathrm{mK})+11 \mathrm{~cm} \text { hollow brick }+1.5 \mathrm{~cm} \text { mortar cement coating }+2 \mathrm{~cm} \text { nonventilated air space }+4 \mathrm{~cm} \\
\text { hollow brick }+1.5 \mathrm{~cm} \text { plastering. }\end{array}$} \\
\hline Ground floor & \multicolumn{2}{|c|}{$10 \mathrm{~cm}$ concrete slab-on-ground $+7.5 \mathrm{~cm} \mathrm{XPS}(\lambda=0.034 \mathrm{~W} / \mathrm{mK})+\mathrm{C} 2 \mathrm{~cm}$ stone paving. } \\
\hline Pitched Roof & \multicolumn{2}{|l|}{ Pitched roof with woden board and ceramic tiles and $20 \mathrm{~cm} \mathrm{XPS}(\lambda=0.034 \mathrm{~W} / \mathrm{mK})$. } \\
\hline Windows & \multicolumn{2}{|l|}{ PVC frame with termal bridge and triple glass. } \\
\hline $\begin{array}{l}\text { Windows } \\
\text { permeability }\end{array}$ & air permeability of $3 \mathrm{~m}^{3} / \mathrm{h}_{-} \mathrm{m}^{2}$ & air permeability of $3 \mathrm{~m}^{3} / \mathrm{h}_{-} \mathrm{m}^{2}$ \\
\hline Ventilation & \multicolumn{2}{|l|}{ Natural admission by windows. $198 \mathrm{l} / \mathrm{s}$ per building } \\
\hline Permeability $\mathrm{n}_{50}$ & \multicolumn{2}{|l|}{ By default $(8,32)$} \\
\hline DHW & \multicolumn{2}{|c|}{281 per person and per day, heated at $60^{\circ} \mathrm{C}$. The energy necessary for lighting and appliances is not considered in this methodology } \\
\hline
\end{tabular}

Table B3

Linear thermal transmittance of thermal bridges $(\mathrm{W} / \mathrm{mK})$.

\begin{tabular}{|c|c|c|c|c|c|}
\hline & & Cádiz & Teruel & Faro & Guarda \\
\hline \multirow[t]{4}{*}{ Wall-To-Wall Junctions: Exterior Corners } & Solution 1 & 0.172 & 0.172 & 0.172 & 0.172 \\
\hline & Solution 2 & 0.11 & 0.08 & 0.172 & 0.172 \\
\hline & Solution 3 & 0.09 & 0.06 & 0.09 & 0.07 \\
\hline & Solution 4 & 0.020 & 0.02 & 0.02 & 0.02 \\
\hline \multirow[t]{4}{*}{ Floor to wall junctions } & Solution 1 & 0.46 & 0.46 & 0.46 & 0.46 \\
\hline & Solution 2 & 0.24 & 0.14 & 0.46 & 0.46 \\
\hline & Solution 3 & 0.17 & 0.09 & 0.50 & 0.12 \\
\hline & Solution 4 & 0.05 & 0.05 & 0.05 & 0.05 \\
\hline \multirow[t]{4}{*}{ Slab-On-Ground } & Solution 1 & 1.303 & 1.303 & 1.303 & 1.303 \\
\hline & Solution 2 & 0.59 & 0.51 & 0.64 & 0.44 \\
\hline & Solution 3 & 0.64 & 0.39 & 0.34 & 0.38 \\
\hline & Solution 4 & 0.28 & 0.28 & 0.28 & 0.28 \\
\hline \multirow[t]{2}{*}{ Window-To-Wall } & Solution 1 & 0.262 & 0.262 & 0.262 & 0.262 \\
\hline & Solution 2 & 0.098 & 0.068 & 0.17 & 0.13 \\
\hline
\end{tabular}


Table B3 (continued)

\begin{tabular}{|c|c|c|c|c|c|}
\hline & & Cádiz & Teruel & Faro & Guarda \\
\hline \multirow{6}{*}{ Pillars } & Solution 3 & 0.093 & 0.06 & 0.09 & 0.065 \\
\hline & Solution 4 & 0.053 & 0.053 & 0.053 & 0.053 \\
\hline & Solution 1 & 1.2 & 1.2 & 1.2 & 1.2 \\
\hline & Solution 2 & 1.2 & 1.2 & 1.2 & 1.2 \\
\hline & Solution 3 & 1.2 & 1.2 & 1.2 & 1.2 \\
\hline & Solution 4 & 1.2 & 1.2 & 1.2 & 1.2 \\
\hline
\end{tabular}

\section{Appendix C}

\section{Table C1}

Emission factors used for the case of Spain and Portugal $[73,74]$.

\begin{tabular}{lc}
\hline Emission factor to $\mathrm{CO}_{2}\left(\mathrm{kgCO}_{2} / \mathrm{kWhEF}\right)$ \\
\hline Portugal & \\
Electricity & 0.360 \\
Natural gas & 0.202 \\
Spain & \\
Electricity & 0.331 \\
Natural gas & 0.252 \\
\hline
\end{tabular}

\section{References}

[1] Official Journal of the European Union, DIRECTIVE (EU) 2018/844 of the EUROPEAN PARLIAMENT and of the COUNCIL of 30 May 2018 Amending Directive 2010/31/EU on the Energy Performance of Buildings and Directive 2012/27/EU on Energy Efficiency, 2018.

[2] EU Parliament, Directive 2010/30 \& 31/EU of the European parliament and of the Council of 19 May 2010, Off. J. Eur. Union - L153 53 (2010) 40. http://eur-lex.eur opa.eu/pri/en/oj/dat/2003/1_285/1_28520031101en00330037.pdf.

[3] D. D'Agostino, L. Mazzarella, What is a Nearly zero energy building? Overview, implementation and comparison of definitions, J. Build. Eng. 21 (2019) 200-212, https://doi.org/10.1016/j.jobe.2018.10.019.

[4] B. Palacios-Munoz, B. Peuportier, L. Gracia-Villa, B. López-Mesa, Sustainability assessment of refurbishment vs. new constructions by means of LCA and durabilitybased estimations of buildings lifespans: a new approach, Build. Environ. 160 (2019) 106203, https://doi.org/10.1016/j.buildenv.2019.106203.

[5] B. Palacios-Munoz, B. López-Mesa, L. Gracia-Villa, Influence of refurbishment and service life of reinforced concrete buildings structures on the estimation of environmental impact, Int. J. Life Cycle Assess. 24 (2019) 1913-1924, https://doi. org/10.1007/s11367-019-01622-w.

[6] Official Journal of the European Union, Recommendations. Commission Recommendation 2019/786 of 8 May 2019 on Buiding Renovation, 2019.

[7] I. Morna, D.P. van Vuuren, Modeling global residential sector energy demand for heating and air conditioning in the context of climate change, Energy Pol. 37 (2009) 507-521, https://doi.org/10.1016/j.enpol.2008.09.051.

[8] M. Santamouris, Cooling the buildings - past, present and future, Energy Build. 128 (2016) 617-638, https://doi.org/10.1016/j.enbuild.2016.07.034.

[9] L. Pajek, M. Košir, Implications of present and upcoming changes in bioclimatic potential for energy performance of residential buildings, Build. Environ. 127 (2018) 157-172, https://doi.org/10.1016/j.buildenv.2017.10.040.

[10] F. Ascione, Energy conservation and renewable technologies for buildings to face the impact of the climate change and minimize the use of cooling, Sol. Energy 154 (2017) 34-100, https://doi.org/10.1016/j.solener.2017.01.022.

[11] Official Journal of the European Union, Recommendation. Comision Recommendation 2019/1019 of 7 June 2019 on Building Modernisation, 2019.

[12] D. Bienvenido-Huertas, M. Oliveira, C. Rubio-Bellido, D. Marín, A comparative analysis of the international regulation of thermal properties in building envelope, Sustainability 11 (2019) 5574, https://doi.org/10.3390/su11205574.

[13] S. Attia, P. Eleftheriou, F. Xeni, R. Morlot, C. Ménézo, V. Kostopoulos, M. Betsi, I. Kalaitzoglou, L. Pagliano, M. Cellura, M. Almeida, M. Ferreira, T. Baracu, V. Badescu, R. Crutescu, J.M. Hidalgo-Betanzos, Overview and future challenges of nearly zero energy buildings (nZEB) design in Southern Europe, Energy Build. 155 (2017) 439-458, https://doi.org/10.1016/j.enbuild.2017.09.043.

[14] A. Fotopoulou, G. Semprini, E. Cattani, Y. Schihin, J. Weyer, R. Gulli, A. Ferrante, Deep renovation in existing residential buildings through façade additions: a case study in a typical residential building of the 70s, Energy Build. 166 (2018) 258-270, https://doi.org/10.1016/j.enbuild.2018.01.056.

[15] R. Escandón, S. Silvester, T. Konstantinou, Evaluating the environmental adaptability of a nearly zero energy retrofitting strategy designed for Dutch housing stock to a Mediterranean climate, Energy Build. 169 (2018) 366-378, https://doi.org/10.1016/j.enbuild.2018.03.079.

[16] E. Iturriaga, U. Aldasoro, J. Terés-Zubiaga, A. Campos-Celador, Optimal renovation of buildings towards the nearly Zero Energy Building standard, Energy 160 (2018) 1101-1114, https://doi.org/10.1016/j.energy.2018.07.023.
[17] L. Guardigli, M.A. Bragadin, F. Della Fornace, C. Mazzoli, D. Prati, Energy retrofit alternatives and cost-optimal analysis for large public housing stocks, Energy Build. 166 (2018) 48-59, https://doi.org/10.1016/j.enbuild.2018.02.003.

[18] B. López-Mesa, M. Monzón-Chavarrías, A. Espinosa-Fernández, Energy retrofit of social housing with cultural value in Spain: analysis of strategies conserving the original image vs. Coordinating its modification, Sustainability 12 (2020) 5579, https://doi.org/10.3390/su12145579.

[19] Ministerio de transportes movilidad y agenda urbana, Actualización 2020 de la estrategia a largo plazo para la rehabilitación energética en el sector de la edificación en España, 2020.

[20] Direçâo Geral de Energia e Geologia, Estratégia Nacional para a Renovação de Edifícios, 2014.

[21] Ministery of Development, Long Term Strategy for Energy Renovation in the Building Sector in Spain Pursuant to Article 4 of Directive 2012/27/UE, 2014.

[22] Statics Portugal, Censos 2011, 2011.

[23] INE, Censo de población y vivienda, 2011.

[24] M. Gangolells, M. Casals, N. Forcada, M. Macarulla, E. Cuerva, Energy mapping of existing building stock in Spain, J. Clean. Prod. 112 (2016) 3895-3904, https:// doi.org/10.1016/j.jclepro.2015.05.105.

[25] L.M. López-González, L.M. López-Ochoa, J. Las-Heras-Casas, C. García-Lozano, Energy performance certificates as tools for energy planning in the residential sector. The case of La Rioja (Spain), J. Clean. Prod. 137 (2016) 1280-1292, https://doi.org/10.1016/j.jclepro.2016.08.007.

[26] J. Las-Heras-Casas, L.M. López-Ochoa, L.M. López-González, J.P. Paredes-Sánchez, A tool for verifying energy performance certificates and improving the knowledge of the residential sector: a case study of the Autonomous Community of Aragón (Spain), Sustain. Cities Soc. 41 (2018) 62-72, https://doi.org/10.1016/j. scs.2018.05.016.

[27] J. Sousa, L. Bragança, M. Almeida, P. Silva, Research on the Portuguese building stock and its impacts on energy consumption - an average U-value approach, Arch. Civ. Eng. 59 (2013) 523-546, https://doi.org/10.2478/ace-2013-0029.

[28] S.M.C. Magalhães, V.M.S. Leal, Characterization of thermal performance and nominal heating gap of the residential building stock using the EPBD-derived databases: the case of Portugal mainland, Energy Build. 70 (2014) 167-179, https://doi.org/10.1016/j.enbuild.2013.11.054.

[29] Official Journal of the European Union, Council Directive 89/106/EEC of 21 December 1988 on the Approximation of Laws, Regulations and Administrative Provisions of the Member States Relating to Construction Products, 1989.

[30] Official Journal of the European Union, Council Directive 93/76/EEC of 13 September 1993 to Limit Carbon Dioxide Emissions by Improving Energy Efficiency (SAVE), 1993.

[31] Official Journal of the European Union, Directive 2002/91/EC of the European Parliament and of the Council of 16 December 2002 on the Energy Performance of Buildings, 2002.

[32] Official Journal of the European Union, Directive 2009/28/EC of the European Parliament and of the Council of 23 April 2009 on the Promotion of the Use of Energy from Renewable Sources, 2009.

[33] Official Journal of the European Union, European Directive 2010/31/EU of 19 May 2010 on the Energy Performance of Buildings, 2010.

[34] Official Journal of the European Union, Directive 2012/27/EU of the European Parliament and of the Council of 25 October 2012 on Energy Efficiency, Amending Directives and Repealing Directives 2004/8/EC and 2006/32/EC, 2012.

[35] Diários da República, Decree-Law 40/90 of 6th February. Regulation of the Characteristics of Thermal Performance of Buildings, RCCTE, 1990. https://dre.pt /application/conteudo/334611. 
[36] Ministério das Obras Públicas Transportes e Comunicações, Decreto-Lei n.O 80/ 2006, 2006

[37] Ministério da Economia e do Emprego, Decreto-Lei n. ${ }^{\circ}$ 118/2013, Diário da República n. ${ }^{\circ}$ 159/2013, Série I de 2013-08-20, 2013. Portugal, Portugal.

[38] Ministério do Ambiente Ordenamento do Território e Energia, Portaria n. ${ }^{\circ}$ 379-A/ 2015, 2015.

[39] Ambiente e Transição Energética, Portaria n. ${ }^{\circ}$ 98/2019, 2019. Portugal.

[40] Diário da República, Portaria 297/2019 de 9 de septembro, 2019.

[41] Itecons, Plataforma para a Eficiência Energética nos Edifícios, Ferram. Cálculo. (2019). http://www.itecons.uc.pt/p3e/. (Accessed 23 October 2019).

[42] BOE, Normativa Básica Edificación sobre Condiciones Térmicas de los edificios (NBE CT 79), 1979.

[43] Ministery of Development, Proyecto de Real Decreto por el que se modifica el RD 314/2006, de 17 de marzo, por el que se aprueba el Código Técnico de la Edificación. Versión para trámite de audiencia e información pública, Ministery of development, Madrid, Spain, 2018.

[44] Ministery of development, Real Decreto 732/2019, de 20 de diciembre, por el que se modifica el Código Técnico de la Edificación, aprobado por el Real Decreto 314/ 2006, de 17 de marzo, 2019.

[45] AENOR, UNE EN ISO 14683:2017 Thermal Bridges in Building Construction -Linear Termal Transmitance - Simplified Methods and Default Values" Define El Parámetro Hx Como Hd "Linear Termal Transmitance, 2017.

[46] Minsterio de transportes movilidad y agenda urbana, Documento Básico de Ahorro de Energía, 2019.

[47] Ministerio de Fomento, Documento descriptivo de climas de referencia. https://www.codigotecnico.org/images/stories/pdf/ahorroEner gia/20170202-DOC-DB-HE-0-Climas de referencia.pdf, 2017.

[48] Diário da República, Despacho 15793-F/2013, 2013.

[49] R. Aguilar, Climatologia e Anos Meteorológicos de Referência para o Sistema Nacional de Certificaçao de Edifícios (versâo 2013), Relatório para ADENEAgência de Energia, 2013.

[50] Energy PLus, Weather Data, (n.d.). https://doi.org/https://energyplus.net/weathe $r$.

[51] F. Kurtz, M. Monzón, B. López-Mesa, Obsolescencia de la envolvente térmica y acústica de la vivienda social de la postguerra española en áreas urbanas vulnerables. El caso de Zaragoza, Inf. La Construcción. 67 (2015) m021, https:// doi.org/10.3989/ic.14.062.

[52] C.A. Pina dos Santos, L. Matias, Coeficientes de transmissâo térmica de elementos da envolvente dos edificios. Versâo actualizada 2006, Laboratóri, Colecçaâo, Lisboa, 2010.

[53] P. Palma, J.P. Gouveia, S.G. Simoes, Mapping the energy performance gap of dwelling stock at high-resolution scale: implications for thermal comfort in Portuguese households, Energy Build. 190 (2019) 246-261, https://doi.org/ 10.1016/j.enbuild.2019.03.002.

[54] A. Brandão de Vasconcelos, M.D. Pinheiro, A. Manso, A. Cabaço, A Portuguese approach to define reference buildings for cost-optimal methodologies, Appl. Energy 140 (2015) 316-328, https://doi.org/10.1016/j.apenergy.2014.11.035.
[55] Instituto Valenciano de Edificación, Catálogo de tipología edificatoria residencial. Ámbito, España, Generalitat Valenciana, Valencia, 2016.

[56] B. Serrano-Lanzarote, L. Ortega-Madrigal, A. García-Prieto-Ruiz, L. Soto-Francés, V.-M. Soto-Francés, Strategy for the energy renovation of the housing stock in Comunitat Valenciana (Spain), Energy Build. 132 (2016) 117-129, https://doi. org/10.1016/j.enbuild.2016.06.087.

[57] E. Cuerda, M. Pérez, J. Neila, Facade typologies as a tool for selecting refurbishment measures for the Spanish residential building stock, Energy Build. 76 (2014) 119-129, https://doi.org/10.1016/j.enbuild.2014.02.054.

[58] G. Semprini, R. Gulli, A. Ferrante, Deep regeneration vs shallow renovation to achieve nearly Zero Energy in existing buildings, Energy Build. 156 (2017) 327-342, https://doi.org/10.1016/j.enbuild.2017.09.044.

[59] S. Aguacil, S. Lufkin, E. Rey, A. Cuchi, Application of the cost-optimal methodology to urban renewal projects at the territorial scale based on statistical data-a case study in Spain, Energy Build. 144 (2017) 42-60, https://doi.org/10.1016/j. enbuild.2017.03.047.

[60] Statistics Portugal, Resultados Preliminares do Inquérito ao Consumo de Energia no Sector Doméstico 2010, 2011.

[61] A. Cuchí, J. Arcas Abella, A. Paggés-Ramón, Estudio de la distribución del consumo energético residencial para calefacción en España, 2017.

[62] Instituto Valenciano de Edificación, Catalogue for Constructive Elements for Retrofiting, 2011.

[63] IDAE, SECH-SPAHOUSEC, 2011.

[64] J. Rose, K.E. Thomsen, O.C. Mørck, M.S.M. Gutierrez, S.Ø. Jensen, Refurbishing blocks of flats to very low or nearly zero energy level-technical and financial results plus co-benefits, Energy Build. 184 (2019) 1-7, https://doi.org/10.1016/j. enbuild.2018.11.051.

[65] F. Harkouss, F. Fardoun, P.H. Biwole, Passive design optimization of low energy buildings in different climates, Energy 165 (2018) 591-613, https://doi.org/ 10.1016/j.energy.2018.09.019.

[66] E. Aparicio-Gonzalez, S. Domingo-Irigoyen, A. Sánchez-Ostiz, Rooftop extension as a solution to reach nZEB in building renovation. Application through typology classification at a neighborhood level, Sustain. Cities Soc. 57 (2020) 102109, https://doi.org/10.1016/j.scs.2020.102109.

[67] IDAE, Escala de calificación energética, Edificios existentes, 2011.

[68] IDAE, Guía técnica, Instalaciones de calefacción individual, 2012.

[69] J. Ortiz, N. Casquero-Modrego, J. Salom, Health and related economic effects of residential energy retrofitting in Spain, Energy Pol. 130 (2019) 375-388, https:// doi.org/10.1016/j.enpol.2019.04.013.

[70] Direçâo Geral de Energia e Geologia, Despacho 15793-I/2013, 2013.

[71] Ministery of Development, Herramienta unificada LIDER-CALENER (HULC). http s://www.codigotecnico.org/index.php/menu-recursos/menu-aplicaciones/282-he rramienta-unificada-lider-calener.html, 2020.

[72] Direçâo Geral de Energia e Geologia, Despacho 15793-K/2013, 2013.

[73] Instituto Eduardo Torroja, Condiciones técnicas de los procedimientos para la evaluación de la eficiencia energética de los edificios, 2019.

[74] D. da República, Despacho 15793-D/2013, 2013. 